Fernanda de Paula

\title{
Mapeamento dos canais de água no processo de morfogênese das glândulas salivares humanas: estudo topográfico das aquaporinas 1, 3 e 5
}

\author{
Dissertação apresentada à Faculdade \\ de Medicina da Universidade de São \\ Paulo para obtenção do título de Mestre \\ em Ciências \\ Programa de Dermatologia \\ Orientador: Prof ${ }^{\circ}$. Dr. Marcello Menta \\ Simonsen Nico
}

(Versão corrigida. Resolução CoPGr 6018/11, de 01 de novembro de 2011. A versão original está disponível na Biblioteca da FMUSP)

São Paulo

2016 
Fernanda de Paula

\title{
Mapeamento dos canais de água no processo de morfogênese das glândulas salivares humanas: estudo topográfico das aquaporinas 1, 3 e 5
}

\author{
Dissertação apresentada à Faculdade \\ de Medicina da Universidade de São \\ Paulo para obtenção do título de Mestre \\ em Ciências \\ Programa de Dermatologia \\ Orientador: Prof ${ }^{\circ}$. Dr. Marcello Menta \\ Simonsen Nico
}

(Versão corrigida. Resolução CoPGr 6018/11, de 01 de novembro de 2011. A versão original está disponível na Biblioteca da FMUSP)

São Paulo

2016 
Dados Internacionais de Catalogação na Publicação (CIP)

Preparada pela Biblioteca da

Faculdade de Medicina da Universidade de São Paulo

Creprodução autorizada pelo autor

Paula, Fernanda de

Mapeamento dos canais de água no processo de morfogênese das glândulas salivares humanas: estudo topográfico das aquaporinas 1, 3 e 5 / Fernanda de Paula. -- São Paulo, 2016.

Dissertação(mestrado)--Faculdade de Medicina da Universidade de São Paulo.

Programa de Dermatologia.

Orientador: Marcello Menta Simonsen Nico.

Descritores: 1.Morfogênese 2.Glândulas salivares 3.Saliva 4.Aquaporinas 5.Imuno-histoquímica 6.Técnicas imunoenzimáticas 7.Feto 


\section{DEDICATÓRIA}




\section{DEDICATÓRIA}

A Deus.

À minha irmã Giovanna Melo de Paula (in memórian). Você, pequena, é minha maior saudade, minha esperança, meu amor

Ao meu marido Ronie dos Santos

À minha família, de sangue ou de coração 
AGRADECIMENTOS 


\section{AGRADECIMENTOS}

Ao meu orientador, Prof. Dr. Marcello Menta Simonsen Nico, por dispor de seu tempo e atenção, auxiliando-me em todos os momentos que precisei. Agradeço a forma tranquila, objetiva e amigável como conduziu tudo até aqui, preocupando-se sempre com o bom andamento deste trabalho.

À Profa. Dra. Silvia Vanessa Lourenço. Obrigada pela oportunidade. Obrigada por me oferecer a chance de estar em seus projetos quando nem eu mesma acreditava ser possível. Sua confiança me trouxe disciplina e coragem. Essa atitude estará para sempre no meu coração. Você me direciona, me ensina, me impulsiona.

Aos meus amigos de laboratório e da vida, Milena Monteiro de Souza Antunes, Ricardo Hsieh e Tathyane Harumi Nakajima Teshima. Fui agraciada com a sorte de conviver com pessoas como vocês no momento mais desafiador da minha vida profissional até agora. Vocês me passaram conhecimentos e experiências profissionais sempre com tanto carinho e paciência, que não me deixaram outra alternativa, além de evoluir no que me foi possível. A gratidão que tenho não cabe nessas palavras.

À Ana Maria Gonçalves da Silva, Thaís Borguezan, Wanessa Siqueira Cavalcante pelo auxílio técnico e suporte, ensinamentos e companheirismo. Vocês fizeram minha trajetória mais amena e alegre durante a confecção deste trabalho.

Ao Prof ${ }^{\circ}$. Dr. Antônio Sesso e à amiga Fernanda Paula Roncon Santana, pela primeira oportunidade de descobrir um laboratório de pesquisa científica.

À Dra. Regina Schultz, por disponibilizar material primordial à confecção deste trabalho.

À todos os profissionais e colegas do Instituto de Medicina Tropical da Faculdade de Medicina da Universidade de São Paulo, pela permissão de 
utilização de toda infraestrutura. Por vezes, a maior parte dos meus dias estive neste lugar. Foi um privilégio estar na companhia de pessoas já tão familiares e agradáveis como vocês.

À Faculdade do Odontologia da Universidade de São Paulo, pela oportunidade de estágio no programa PAE, contribuindo para minha formação acadêmica.

À CAPES, por auxiliar e incentivar meu desenvolvimento profissional contemplando-me com a bolsa de mestrado. 
Esta dissertação ou tese está de acordo com as seguintes normas, em vigor no momento desta publicação:

Referências: adaptado de International Committee of Medical Journals Editors (Vancouver).

Universidade de São Paulo. Faculdade de Medicina. Divisão de Biblioteca e Documentação. Guia de apresentação de dissertações, teses e monografias. Elaborado por Anneliese Carneiro da Cunha, Maria Julia de A. L. Freddi, Maria F. Crestana, Marinalva de Souza Aragão, Suely Campos Cardoso, Valéria Vilhena. 3a ed. São Paulo: Divisão de Biblioteca e Documentação; 2011.

Abreviaturas dos títulos dos periódicos de acordo com List of Journals Indexed in Index Medicus. 


\section{SUMÁRIO}

\section{LISTA DE FIGURAS}

\section{LISTA DE TABELAS}

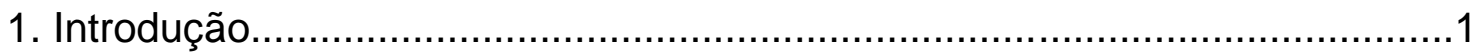

2. Objetivos

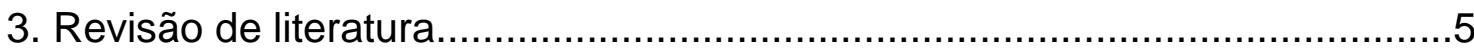

3.1. Morfogênese das glândulas salivares................................................

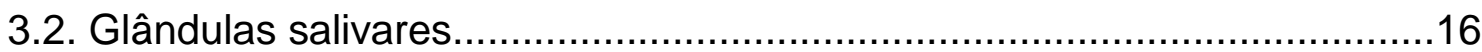

3.3. Glândulas salivares maiores..............................................................17

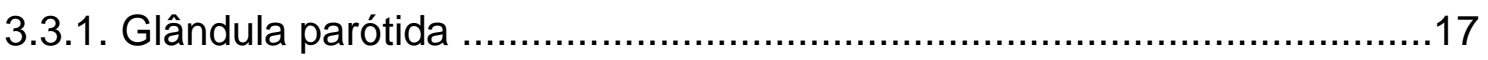

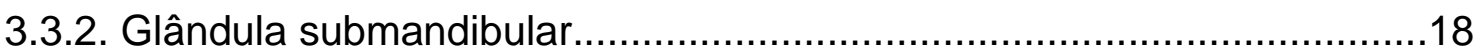

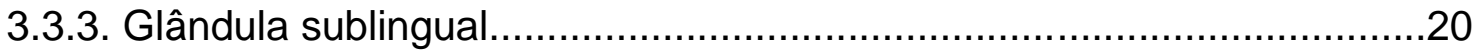

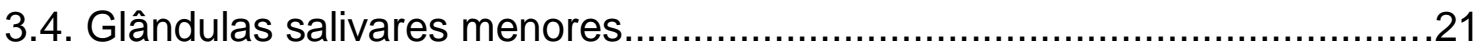

3.5. As células componentes das glândulas salivares....................................22

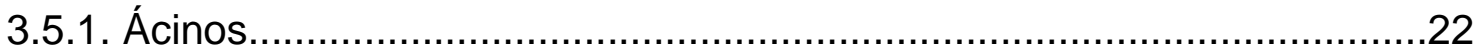

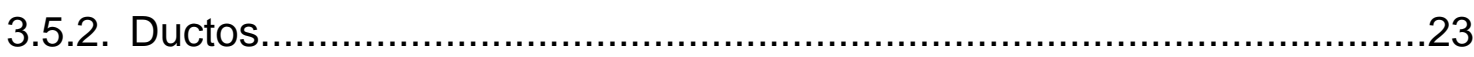

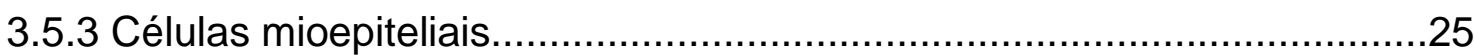

3.6. Suprimento nervoso das glândulas salivares........................................26

3.7. Suprimento sanguíneo das glândulas salivares......................................28

3.8. Saliva

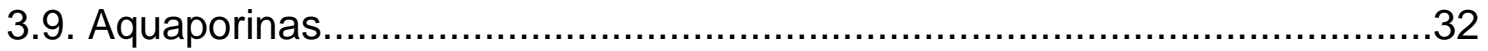

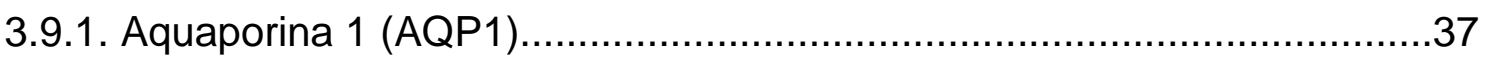

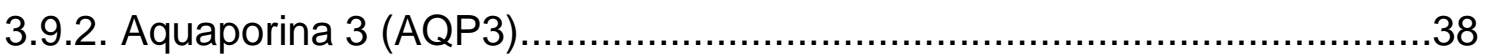




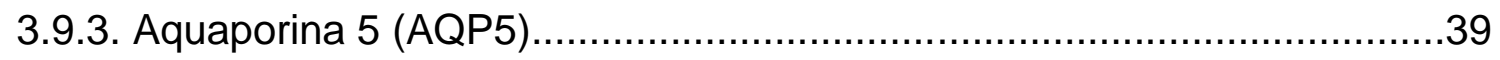

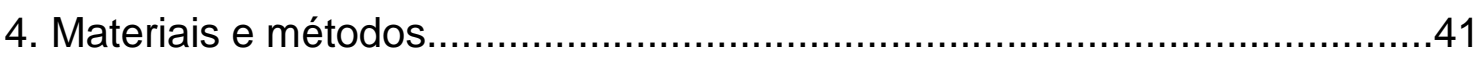

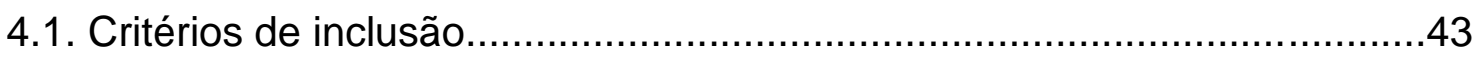

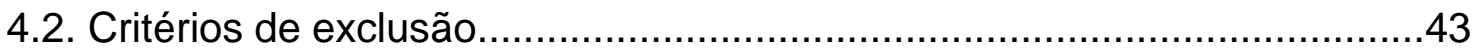

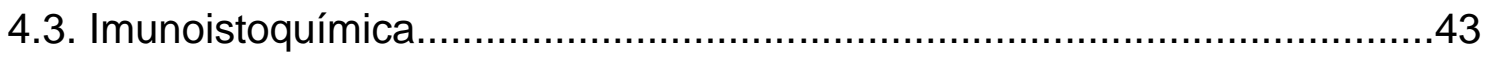

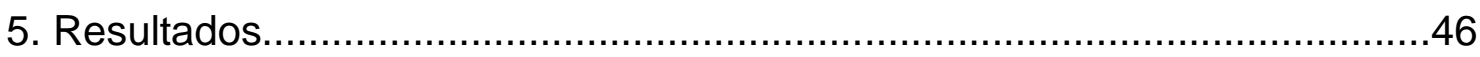

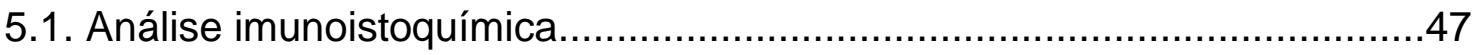

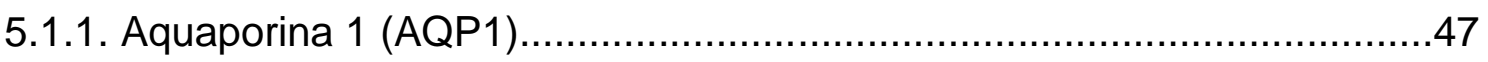

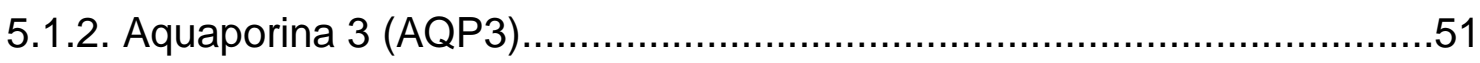

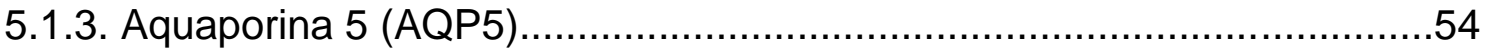

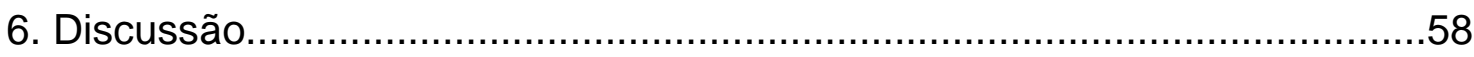

7. Conclusão

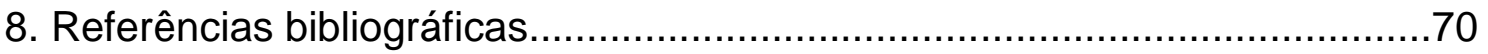

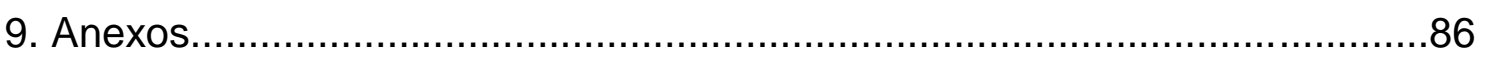

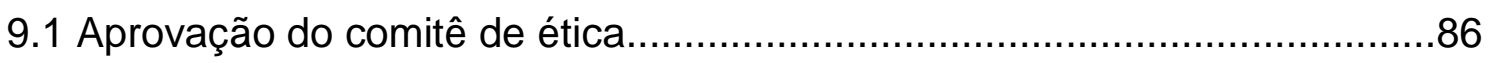




\section{LISTAS}




\section{LISTA DE FIGURAS}

Figura 1: Diagrama esquemático da fase pré-botão da morfogênese das glândulas salivares.

..8

Figura 2: Diagrama esquemático da fase de botão inical da morfogênese das glândulas salivares.

.9

Figura 3: Diagrama esquemático da fase pseudoglandular da morfogênese das glândulas salivares. 11

Figura 4: Diagrama esquemático da fase canalicular da morfogênese das glândulas salivares.

Figura 5: Diagrama esquemático da fase botão final da morfogênese das glândulas salivares. 14

Figura 6: Estágios morfogenéticos das glândulas salivares humanas (hematoxilina/eosina) 15

Figura 7: Estrutura acinar no processo de transformação da saliva primária para secundária.

Figura 8: Esquema ilustrando abertura de passagem entre os meios extra e intracelular da bicamada fosfolipídica da membrana plasmática através da aquaporina. .34

Figura 9: Topologia de uma proteína aquaporina no interior da bicamada fosfolipídica da membrana plasmática. .35

Figura 10: Dissecção das glândulas salivares nos fetos humanos. 42

Figura 11: Expressão da proteína aquaporina 1 durante o desenvolvimento das glândulas salivares de fetos humanos. .50

Figura 12: Expressão da proteína aquaporina 3 durante o desenvolvimento das glândulas salivares de fetos humanos. 
Figura 13: Expressão da proteína aquaporina 5 durante o desenvolvimento das glândulas salivares de fetos humanos.. .56 


\section{LISTA DE TABELAS}

Tabela 1: Dados dos anticorpos primários utilizados no estudo em glândulas salivares humanas, com respectivos clones e códigos, titulações utilizadas, controles, procedências e modo de recuperação antigênica.............................45

Tabela 2: Análise da expressão das aquaporinas nas diferentes fases do desenvolvimento fetal das glândulas salivares humanas. 


\section{RESUMO}




\section{RESUMO}

Paula F. Mapeamento dos canais de água no processo de morfogênese das glândulas salivares humanas: estudo topográfico das aquaporinas 1, 3 e 5 [Dissertação]. São Paulo: Faculdade de Medicina, Universidade de São Paulo; 2016.

Introdução: As glândulas salivares humanas passam por diversos e complexos processos durante o período de desenvolvimento, até que adquiram maturidade estrutural para desempenhar sua função, a formação e secreção de saliva. Considerada essencial à saúde e homeostase da cavidade oral, a saliva é um fluido aquoso que depende de um mecanismo de transporte entre as membranas celulares por meio das aquaporinas. A família de proteínas aquaporinas possui treze membros. Somente algumas dessas proteínas atuam nas glândulas salivares formando poros na bicamada lipídica das membranas celulares facilitando o transporte de água e pequenos solutos, cruciais à regulação da qualidade e quantidade de saliva secretada. Proposição: Diante deste cenário, avaliamos por meio da técnica de imunoistoquímica o padrão de expressão das aquaporinas 1,3 e 5 de glândulas salivares em desenvolvimento, com o intuito de contribuir com informações de base para futuras pesquisas. Metodologia: 47 espécimes parafinados de glândulas salivares em desenvolvimento, de diferentes sítios da cavidade oral de 20 fetos humanos, com idade entre 14 e 25 semanas, foram submetidos à técnica de imunoperoxidase. Os resultados foram analisados, de acordo com o estágio da morfogênese glandular e localização da expressão das aquaporinas. Resultados: $\mathrm{Na}$ fase de botão, houve a expressão das aquaporinas 1, 3 e 5 em todas as células epiteliais; na fase pseudoglandular, a expressão dessas proteínas foi vista nos ductos rudimentares (com exceção da aquaporina 1) e nas porções terminais (futuros ácinos); na fase canalicular as aquaporinas foram principalmente detectadas nos ácinos rudimentares e ductos. Finalmente, na fase de botão terminal, as aquaporinas 3 e 5 foram detectadas 
nas membranas das células acinares e os ductos expressaram todas as aquaporinas. Conclusão: $O$ presente trabalho evidenciou a imunoexpressão das aquaporinas 1, 3 e 5 nas glândulas salivares humanas durante o período de embriogênese. A análise topográfica dessas proteínas nos permitiu identificar diferenças no padrão de expressão entre as diferentes regiões estruturais e estágios do desenvolvimento glandular, sugerindo diferentes papéis para cada proteína.

Descritores: morfogênese; glândulas salivares; saliva; aquaporinas; imuno-histoquímica; técnicas imunoenzimáticas; feto. 


\section{ABSTRACT}




\section{ABSTRACT}

Paula F. Mapping of water channels in the morphogenesis process of human salivary glands: topographic study of aquaporins 1, 3 and 5 [Dissertation]. São Paulo: "Faculdade de Medicina, Universidade de São Paulo"; 2016.

Introduction: The human salivary glands morphogenesis depends on complex processes during the development period until they reach full structural maturity to perform its function - the synthesis and secretion of saliva. The saliva is a complex aqueous fluid considered essential to health and homeostasis of the oral cavity; its synthesis depends on several molecular mechanisms, including the transport of water, solutes, ions, amongst others across the cell membranes. The aquaporin family of proteins is essential in this process. This protein family consists of thirteen members that form channels across the cell membrane facilitating water and small solutes transportation, crucial to the regulation of quality and quantity of secreted saliva. Aims: In this scenario, we evaluated, using the immunohistochemistry technique, the expression pattern of aquaporins 1,3 and 5 in the different phases of salivary glands development, in order to understand the role of these protein in the formation of human salivary gland morphogenesis. Methodology: 47 specimens of paraffin embedded human salivary glands at various developmental phases were included in the study. The specimens were derived from various sites of the oral cavity of 20 human fetuses aged between 14 and 25 weeks of gestation. All specimens were subjected to the imunohistochemical immunoperoxidase technique. The results were qualitatively and semiquantitatively analyzed according to the stage of glandular morphogenesis and express location of aquaporin. Results: In the bud stage, there was expression of aquaporin 1, 3 and 5 in all glandular epithelial cells; in pseudoglandular stage, the expression of these proteins was seen in rudimentary ducts (except aquaporin-1) and the terminal end buds (future acini); in the canalicular phase the aquaporins were mainly detected in the rudimentary ducts and acini. Finally, in terminal bud stage, the aquaporin 3 and 5 were detected in the membranes of the ducts and acinar cells expressed all aquaporins. Conclusion: This study showed the presence of aquaporins 1 , 3 and 5 in human salivary glands during embryogenesis period. The topographic analysis of these proteins allowed us to identify differences in the expression pattern between the different structural regions and stages of glandular development, suggesting different roles for each of these proteins. 
Descriptors: morphogenesis; salivary glands; saliva; aquaporins; immunohistochemistry; immunoenzyme techniques; fetus. 
1. INTRODUÇÃO 


\section{INTRODUÇÃO}

Durante o período de morfogênese das glândulas salivares humanas ocorrem diversos processos que envolvem uma série de movimentos coordenados e interações recíprocas entre epitélio e mesênquima. Este dinâmico processo contribui para a evolução da arquitetura tecidual e resulta em estruturas capazes de produzir e secretar a saliva para o interior da cavidade oral (Hogan, 1999; Loureço et al; 2008; Nelson et al., 2013).

A saliva é um fluido aquoso composto também por eletrólitos e proteínas que tem participação valiosa na proteção e hidratação na mucosa da cavidade oral, contribuindo para a manutenção da homeostase. Para que a secreção salivar ocorra, o movimento de água entre as membranas celulares é facilitado por proteínas denominadas aquaporinas (Edgar, 1992; Dodds et al., 2005; Delporte, 2013).

As aquaporinas são uma família de proteínas capazes de formar poros em membranas celulares e facilitar o transporte de água e pequenos solutos. No total, 13 destas proteínas já foram encontradas e descritas de acordo com sua especificidade em cada órgão do corpo humano sendo divididas em três subgrupos: as aquaporinas, capazes de transportar somente água, as aquagliceroporinas, capazes de transportar água e pequenos solutos como ureia e glicerol e as superaquaporinas ou aquaporinas não clássicas, pois sua permeabilidade é incerta (Borgnia et al., 1999; Kozono et al., 2002; Verkman, 2005; Delporte e Steinfield, 2006; Ishibashi et al., 2014).

Com base na importante função desempenhada por algumas destas proteínas nas glândulas salivares humanas, o presente estudo objetiva identificar e descrever se a expressão das aquaporinas 1, 3 e 5 ocorre durante o período de embriogênese das glândulas salivares humanas, em qual estágio do desenvolvimento expressam-se e os sítios da estrutura tecidual glandular em que estão localizadas. 
2. OBJETIVOS 


\section{OBJETIVOS}

As glândulas salivares humanas são responsáveis pela produção e transporte da saliva para o interior da cavidade oral. Para que isso ocorra, o transporte de água entre as membranas celulares é facilitado por proteínas de canais de membrana chamadas aquaporinas. Até o momento, não há registros de estudo da expressão das aquaporinas durante a embriogênese das glândulas salivares humanas. Assim, baseando-se na importante função desempenhada por algumas destas aquaporinas nas glândulas salivares humanas, o presente estudo objetiva:

- Identificar e descrever se há expressão das aquaporinas 1, 3 e 5 durante 0 período de embriogênese das glândulas salivares humanas.

\section{OBJETIVOS ESPECÍFICOS}

- Descrever o perfil de expressão das aquaporinas 1,3 e 5 de acordo com cada estágio morfogenético das glândulas salivares humanas;

- Determinar a localização intracelular e quais tipos celulares apresentam a expressão das aquaporinas 1, 3 e 5 nas glândulas salivares humanas fetais. 
3. REVISÃO DE LITERATURA 


\section{REVISÃO DE LITERATURA}

\subsection{MORFOGÊNESE DAS GLÂNDULAS SALIVARES}

Todos os órgãos do corpo humano adquirem a morfologia necessária ao funcionamento ideal durante o desenvolvimento embriológico partindo de um precursor primitivo. A este processo dá-se o nome organogênese (Otani et al., 2010)

Durante o período de organogênese, células especializadas como as do tecido muscular, neuronal e cartilaginoso se diferenciam passando por duas fases distintas: a morfogênese (crescimento e rearranjo celular formando uma complexa estrutura tridimensional), e a citodiferenciação (processo onde estas células assumem funções especializadas). O desenvolvimento embrionário passará pelas etapas de segmentação ou clivagem, mórula, blástula, gastrulação e neurulação. (Junqueira e Zago, 1982; Lu et al., 2006; Lu e Werb, 2008; Wolpert et al., 2015)

O desenvolvimento de órgãos secretores como as glândulas salivares passam por um processo de embriogênese similar e dependem de um mecanismo denominado morfogênese de ramificação, ou simplesmente ramificação (Denny et al., 1997; Carlson, 2000; Lourenço et al., 2007, 2008, Varner e Nelson, 2014).

A ramificação é um processo crucial ao desenvolvimento das glândulas salivares e é orquestrada por interações entre epitélio e mesênquima. Envolve a coordenação de mecanismos que incluem expressão gênica e regulação de mudanças do formato celular, através das etapas de crescimento, proliferação, diferenciação, migração, apoptose e interação epitelial, mesenquimal, endotelial e neuronal. Partindo de um simples botão epitelial precursor, a 
migração celular dirigida leva ao total desenvolvimento da glândula salivar e sua importante função secretora (Cutler, 1990; Dale, 1994; Klein, 1994; Kashimata e Gresik, 1996; Patel et al., 2006; Larsen et al., 2010; Nelson et al., 2013; Patel e Hoffman, 2014).

A partir do epitélio do estomodeo, também conhecido como cavidade oral primitiva, dá-se início à proliferação de um cordão epitelial sólido, que adentra o ectomesênquima subjacente, ramificando-se extensivamente, levando à formação de um sistema ductal e, ao final destes, os ácinos secretores (Cutler, 1990, Kashimata e Gresik, 1996; Carlson, 2000; Ellis e Auclair, 2008).

Utilizando modelo animal (embrião de camundongos), alguns autores descreveram as fases do desenvolvimento das glândulas salivares. Esse modelo foi resumido na excelente revisão de Tucker, 2007:

Conhecido como estágio PRÉ-BOTÃo, o período em que as células epiteliais se proliferam iniciando os primeiros sinais de desenvolvimento da glândula salivar submandibular, ocorre por volta do $11^{\circ}$ dia de vida embrionária (Figura 1) (Macauley et al., 1997; Jaskoll e Melnick, 1999, Melnick e Jaskoll, 2000). 


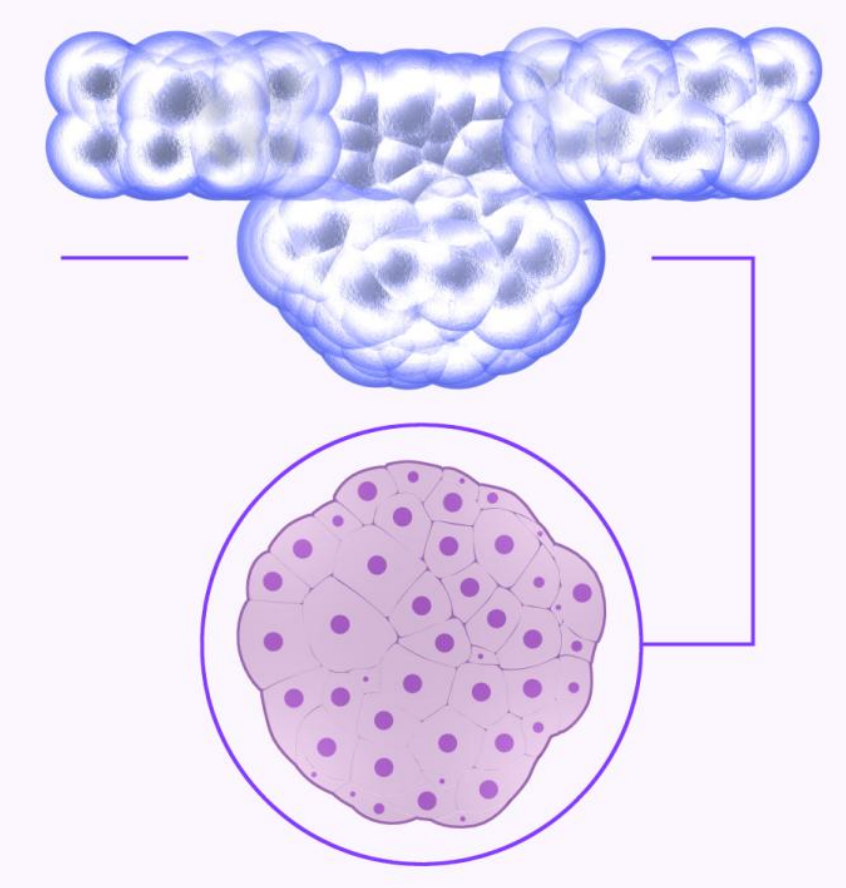

Figura 1: Diagrama esquemático da fase pré-botão da morfogênese das glândulas salivares. Notar o início da formação de agregado de células epiteliais a partir do estomodeo.

Por volta do $12^{\circ}$ dia de vida embrionária, a glândula salivar inicia-se como uma estrutura epitelial esférica na qual há espessamento do tecido glandular embrionário, que se invagina ao mesênquima e começa a condensar. $O$ botão epitelial cresce adentrando 0 tecido mesenquimal formando um botão primário em um cordão. Da crista neural derivam precursores que se coalescem para formar o gânglio submandibular parassimpático, invólucro em torno do cordão. Os sinais que iniciam essa interação não estão bem definidos, mas pode-se definir esta fase como ESTÁGIO DE BOTÃO INICIAL (Figura 2) (Jaskoll e Melnick, 1999; Melnick e Jaskoll, 2000; Knox \& Hoffman, 2008; Hsu e Yamada, 2010; Patel e Hoffman, 2014). 


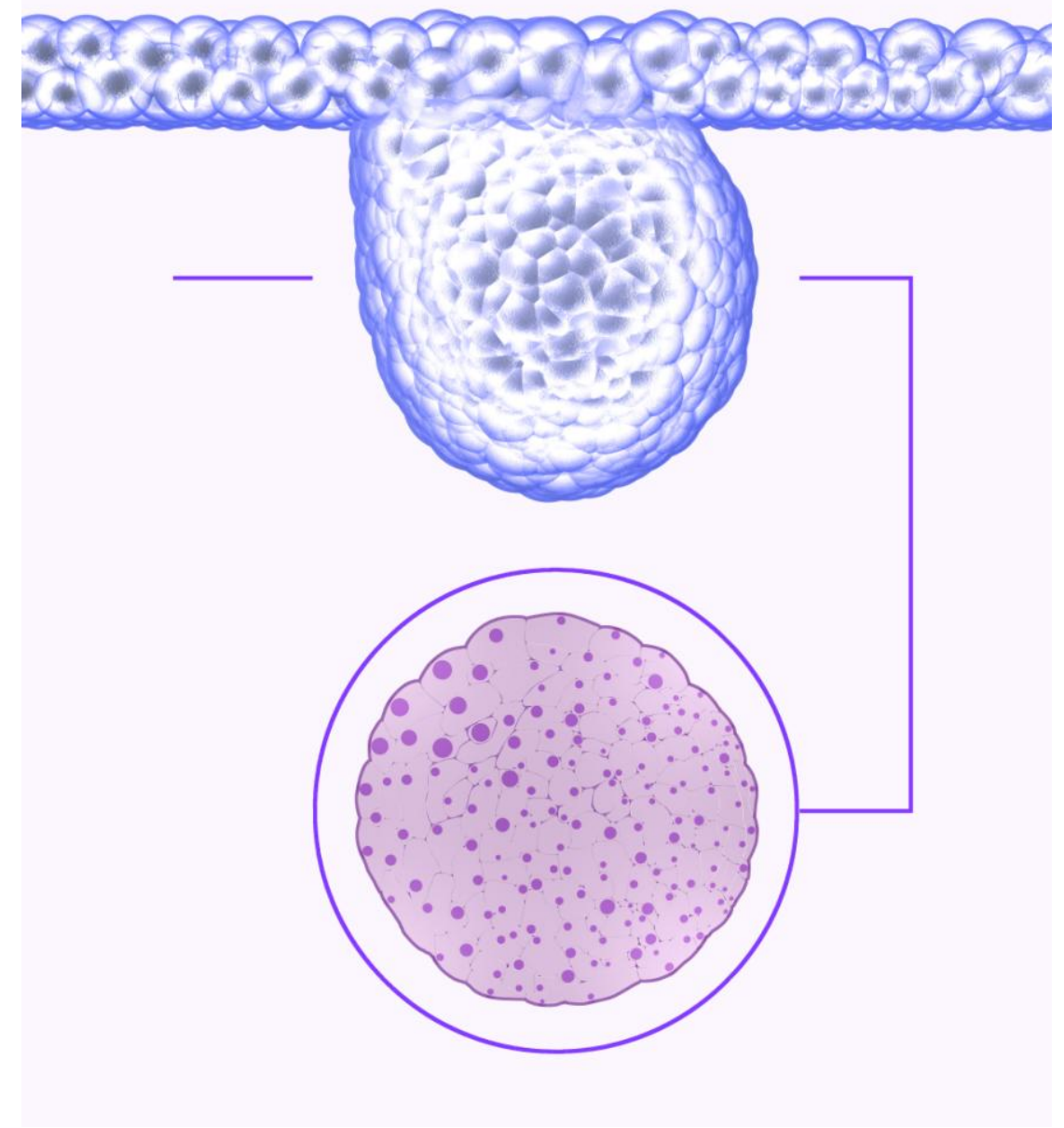

Figura 2: Diagrama esquemático da fase de botão inical da morfogênese das glândulas salivares. Observar um nódulo bem formado e sólido que se invagina no mesênquima. 
Conhecido como estágio PSEUDOGLANDULAR, este botão passa por ramificações formando cachos de ramos e botões em suas extremidades (Figura 3). Nessa fase, os cachos e ramos subdividem-se formando múltiplos brotos ou botões (Jaskoll e Melnick, 1999; Melnick e Jaskoll, 2000)

No $13^{\circ}$ dia de vida embrionária existem aproximadamente 4 a 5 botões na glândula submandibular. $O$ processo de morfogênese da ramificação repetese inúmeras vezes durante dias e de forma contínua, aumentando a complexidade do órgão. Axônios do gânglio submandibular parassimpático estendem-se ao longo do epitélio envolvendo os botões finais (Jaskoll e Melnick, 1999; Melnick e Jasckoll, 2000,Hsu e Yamada, 2010; Knox e Hoffman, 2008, Teshima et al., 2016)

Por volta do $14^{\circ}$ dia de vida embrionária, os botões continuam as ramificações produzindo uma glândula multi-lobulada bem como alongamento dos ductos e uma estrutura altamente ramificada (Jakoll e Melnick, 1999; Hsu e Yamada, 2010; Knox et al., 2010) 


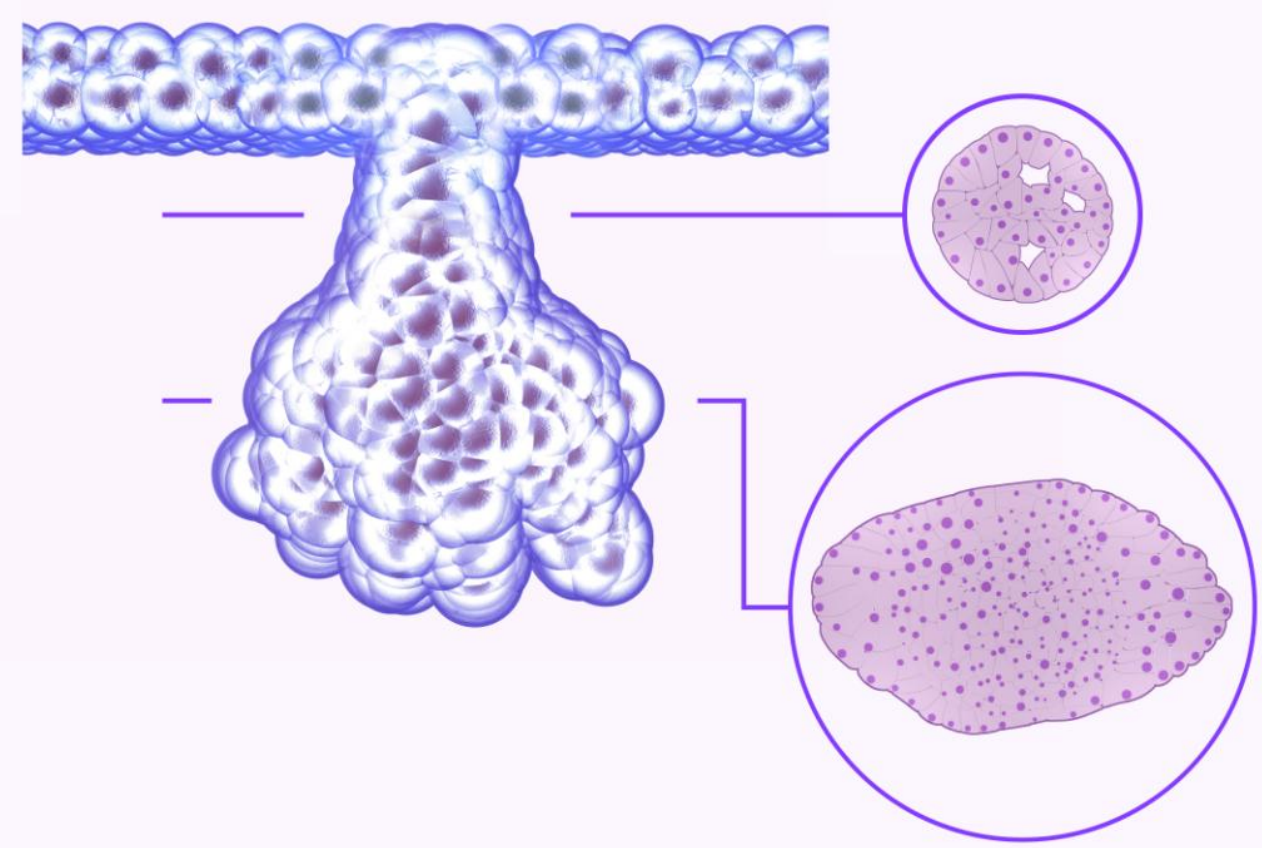

Figura 3: Diagrama esquemático da fase pseudoglandular da morfogênese das glândulas salivares. Observar, no detalhe, a presença do início de formações terminais sólidas oriundas das múltiplas proliferações e ramificações das células epiteiais e o início rudimentar da canalização (abertura dos lúmens). 
O estágio CANALICULAR inicia-se por volta do $15^{\circ}$ dia de vida de vida embrionária (Figura 4). As células epiteliais proliferam ativamente em torno da formação de seu lúmen e é neste momento que a maioria dos ductos se desenvolvem. Sugere-se que a formação luminal seja iniciada com a morte das células centrais que presumivelmente sofrem apoptose (Jaskol e Melnik 1999, Tucker, 2007).
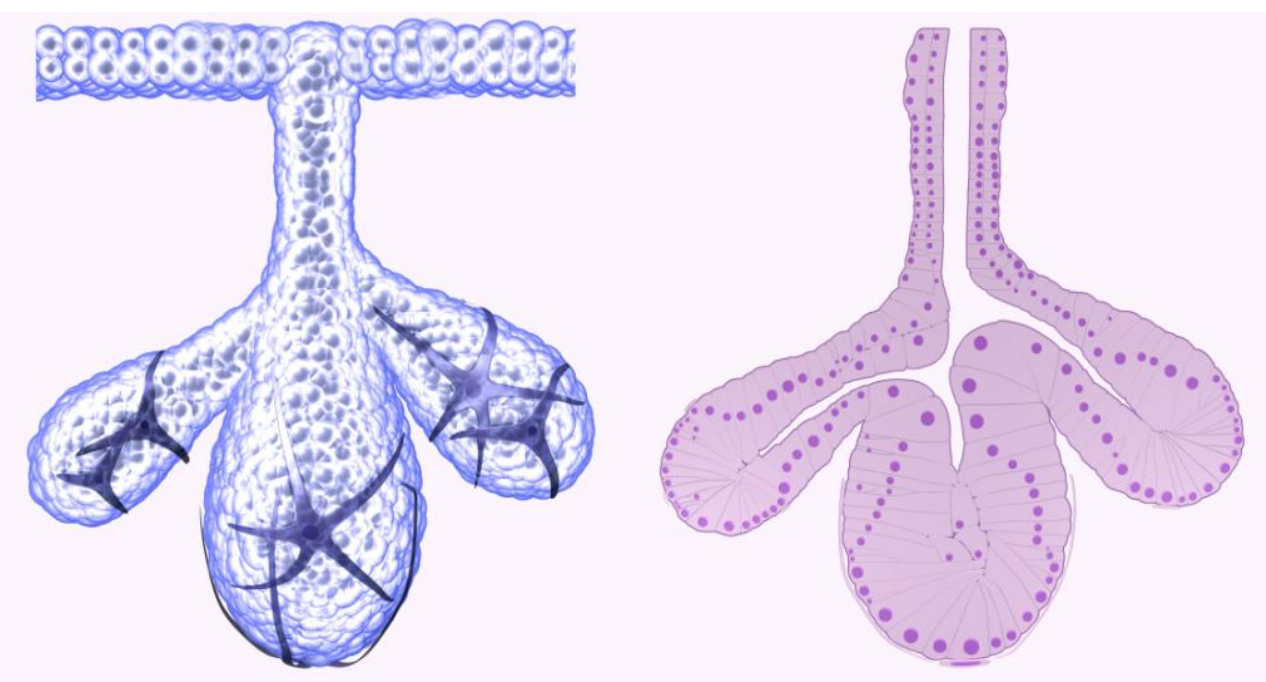

Figura 4: Diagrama esquemático da fase canalicular da morfogênese das glândulas salivares. Notar a canalização dos ductos glandulares, e o início da presença das células mioepiteliais. 
Por volta do $17^{\circ}$ dia de vida embrionária, os ramos e botões são escavados para formar ductos e ácinos. O estágio de BOTÃO TERMINAL é alcançado (Figura 5) (Jaskol e Melnick; 1999; Melnick e Jaskoll, 2000; Tucker, 2007).

Lúmens bem desenvolvidos distintos podem ser verificados neste estágio, assim como possíveis ductos. Não esta ainda completa, porém, a continuidade entre ductos e lúmens capazes de conectar os ácinos à cavidade oral (Melnick e Jaskoll, 2000).

Túbulos granulares contorcidos decorrentes da puberdade continuam diferenciando-se e as glândulas permanecem maturando no período pós-natal com o final da diferenciação (Gresik, 1994).

A proliferação é relativamente baixa no mesênquima em todos os estágios de desenvolvimento glandular, mas é alta no epitélio (Jaskol e Melnik, 1999).

O epitélio da glândula salivar pode ser isolado do mesênquima por volta do $13^{\circ}$ dia de vida embrionária e continuará seu crescimento e ramificação se cultivadas na matriz extracelular. Além disso, as moléculas provenientes da matriz extracelular são elementos essenciais ao desenvolvimento das glândulas salivares e orientam a arquitetura de tecidos e órgãos (Cutler, 1990; Tucker, 2007; Melnick e Jaskoll, 2000, Hsu e Yamada, 2010).

Um sólido núcleo de células epiteliais iniciam a formação das glândulas salivares, desta forma, a correta função dos ductos das glândulas salivares necessitam submeter-se à cavitação para permitir o livre acesso entre a cavidade oral e a produção de saliva pelos ácinos (Tucker, 2007).

A Figura 6 ilustra, histologicamente as fases da morfogênese das glândulas salivares de embriões humanos. 


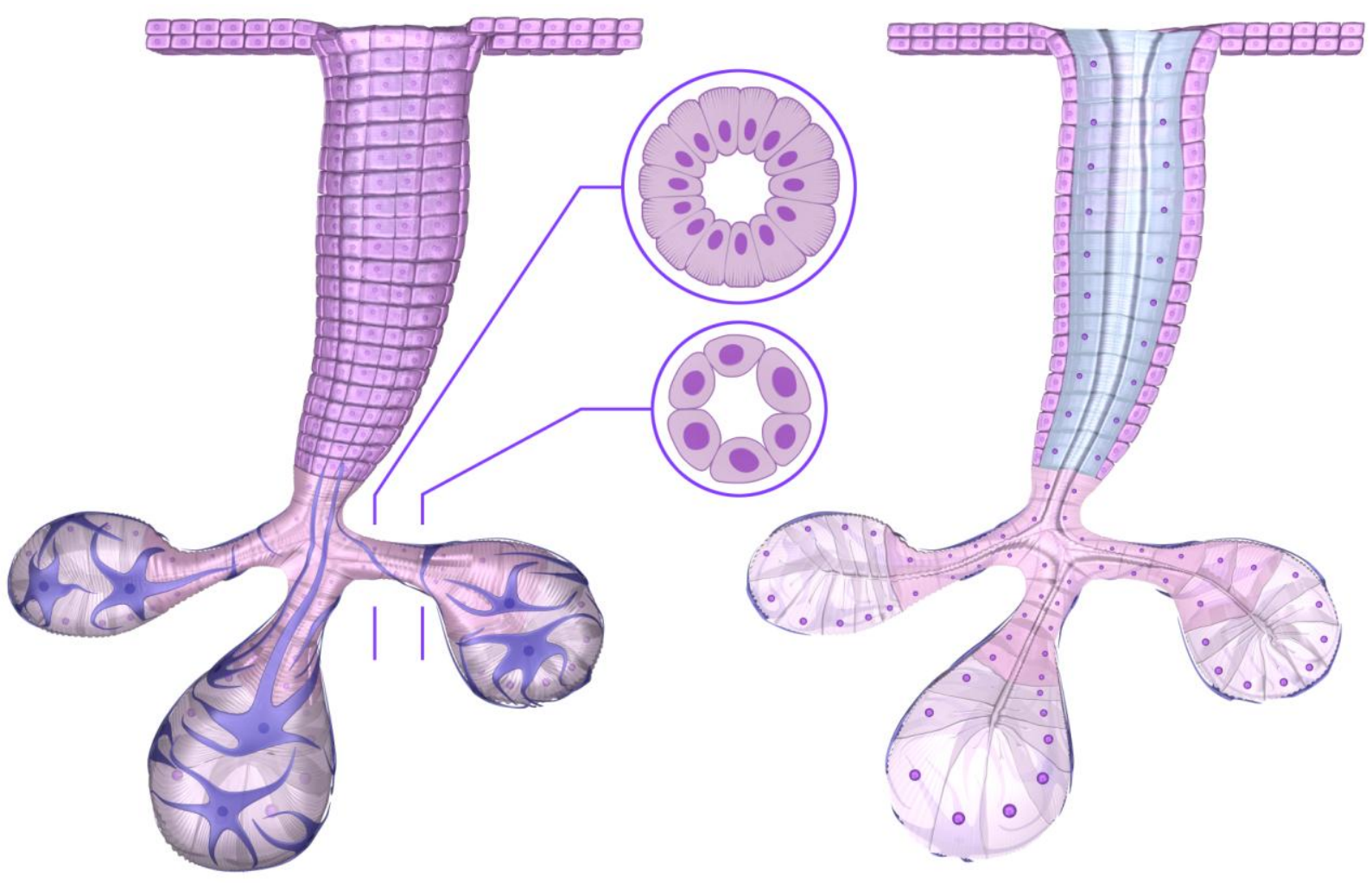

Figura 5: Diagrama esquemático da fase botão final da morfogênese das glândulas salivares. Nessa fase a glândula salivar encontra-se com a sua morfogênese completa. 


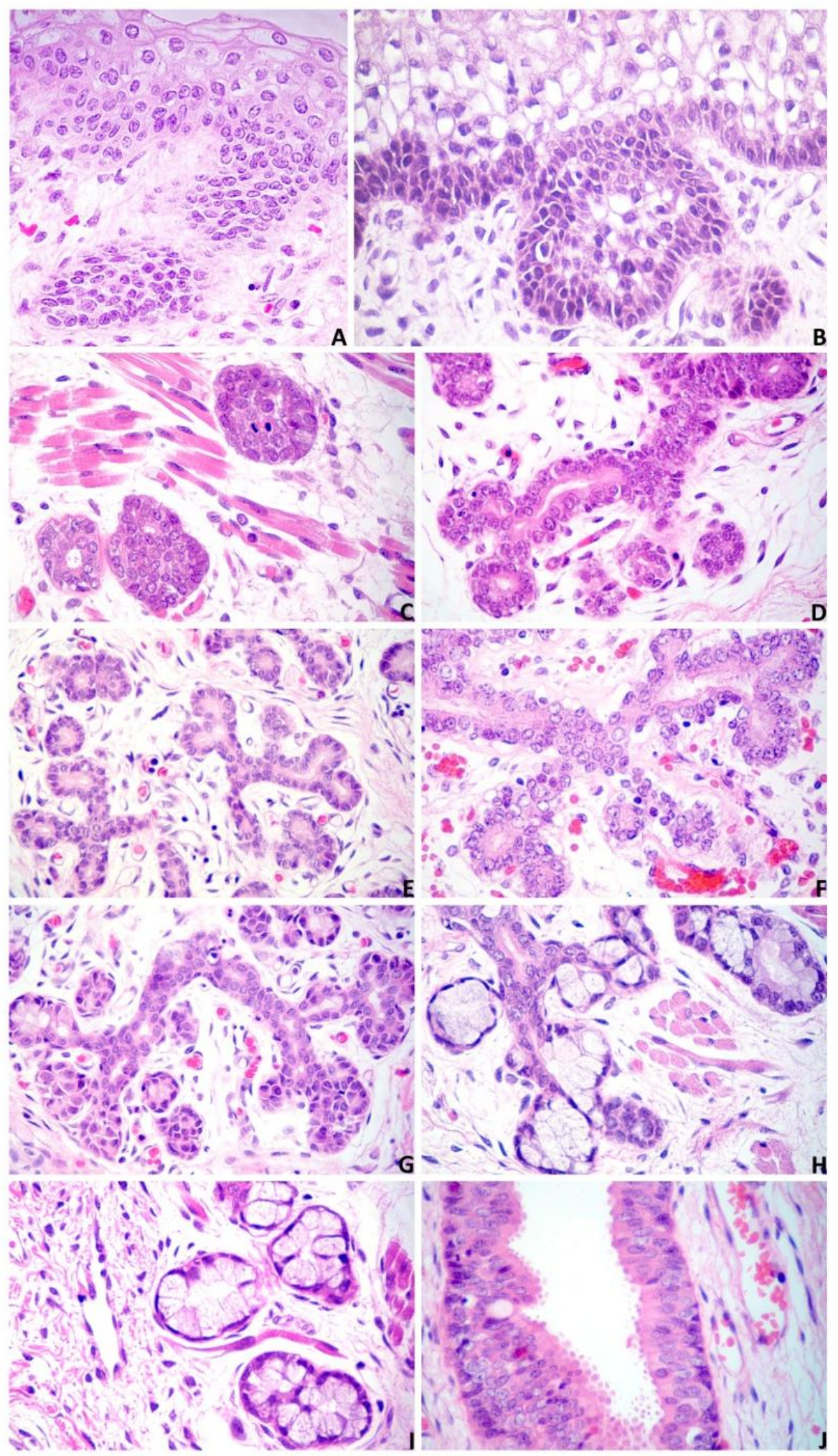

Figura 6: Estágios morfogenéticos das glândulas salivares humanas (hematoxilina-eosina). A/B: Estágio de botão inicial; C/D: Estágio pseudoglandular; E/F: Estágio canalicular; $\mathbf{G / H} / \mathrm{I} / \mathrm{J}$ : Estágio de botão terminal. Magnificação original: A/B/C 630x; D/F/H/I/J 400x; E/G 200x. 


\subsection{GLÂNDULAS SALIVARES}

A origem epitelial das glândulas salivares ainda é controvérsia na literatura. Questiona-se se esta ocorre a partir do epitélio ectodermal ou endodermal. A elucidação pode vir através do rastreamento de linhagens genéticas. As respostas ainda são conflitantes, porém, sugere-se que a glândula parótida tenha origem ectodermal, enquanto as glândulas submandibulares e sublinguais sejam originadas a partir da endoderme (Avery, 2002).

O sistema salivar em humanos possui três pares de glândulas principais, a glândula parótida, glândula submandibular e glândula sublingual. Juntas, são responsáveis por $90 \%$ do total de secreção, além das glândulas salivares menores espalhadas no interior da cavidade oral, somando de 600 a 1000 glândulas (Edgar, 1990; Amano et al., 2012; Holmberg \& Hoffman, 2014).

As glândulas salivares consistem de células especializadas derivadas do epitélio com dois segmentos funcionais razoavelmente bem definidos morfologicamente. Sua estrutura é constituída por células acinares e um complexo sistema de ductos glandulares, além das células mioepiteliais (Edgar, 1992; Ten Cate, 2013).

Quanto aos ductos, existem três tipos: ducto intercalado, ducto estriado e ducto excretor. O fluxo salivar passa dos ácinos aos ductos através do auxílio das células mioepiteliais antes de desembocar no interior da cavidade oral (Katchburian e Arana, 2014).

As células mioepiteliais que circundam os ácinos e ductos intercalares são inervadas com a proposta de facilitar a secreção pela contração (lanez et al., 2010). 


\subsection{GLÂNDULAS SALIVARES MAIORES}

\subsubsection{GLÂNDULA PARÓTIDA}

A glândula parótida inicia seu desenvolvimento entre a $5^{\mathrm{a}}$ e $6^{\mathrm{a}}$ semana de vida intrauterina (Ellis e Auclair, 2008).

É a maior glândula entre as três principais. Localizada de cada lado da face, com o peso médio de 25 a 30 gramas, situa-se entre o músculo esternocleidomastóideo e a borda posterior do ramo da mandíbula. Acima, se limita com a articulação temporomandibular e o meato acústico cartilagíneo e abaixo se estende até o ângulo da mandíbula. Possui uma parte superficial conectada por um ístmo a uma parte profunda. Ambas as partes abraçam a mandíbula. A parte superficial, maior, recobre grande parte do músculo masseter (Berkovitz et al., 1992; Carlson, 2000; Ferraris e Munõz, 2006; Madeira, 2008; Katchburian \& Arana, 2014).

O ducto de Stensen é o principal conduto desta glândula, passando pela borda anterolateral da glândula parótida sobre o músculo masseter atravessando-o para que possa desembocar na altura do primeiro ou segundo molar superior, em uma pequena papila na mucosa jugal (Berkovitz et al., 1992, Carlson, 2000; Ferraris e Munõz, 2006; Holmberg e Hoffman, 2014; Katchburian e Arana, 2014).

As glândulas parótidas possuem ductos interlobulares bem desenvolvidos. Já os condutos intercalares particularmente são muito longos. Os ductos estriados são numerosos. Possuem células claras e escuras e podem aparecer como ductos ligeiramente acidófilos, além de um epitélio simples colunar ou cilíndrico com núcleos arredondados centrais. Alguns dos 
lúmens ductais desta glândula são maiores que os ácinos e são revestidos por células epiteliais cúbicas (Ferraris e Munõz, 2006; Ten Cate, 2013).

A glândula parótida é composta por ácinos serosos que produzem uma saliva mais aquosa ou líquida, rica em amilase, sulfomucinas e sialomucinas. Este é o par de glândulas que sintetizam a maior quantidade de saliva (Berkovitz et al., 1992; Ferraris e Munõz, 2006).

É uma glândula composta com divisões nítidas de seus lobos e lóbulos, além de uma cápsula espessa. Possui células em formato piramidal com núcleo esférico no citoplasma basal. Existe uma grande quantidade de tecido adiposo nos lóbulos e entre as divisões lobulares. Esses adipócitos podem aumentar com a idade e substituir o tecido parenquitomatoso funcional. Incorporados a esta glândula durante o desenvolvimento, o estroma parotídeo apresenta um ou mais linfonodos que, por vezes, são atravessados por ductos glandulares (Ferraris e Munõz, 2006; Ten Cate, 2013; Katchburian e Arana, 2014).

As parótidas são inervadas pelo nervo auriculotemporal e plexo simpático da carótida externa (Katchburian e Arana, 2014).

\subsubsection{GLÂNDULA SUBMANDIBULAR}

Interações recíprocas em torno do epitélio, crista neural derivada do mesênquima, nervos e vasos sanguíneos, regulam eventos que originam a glândula submandibular. O início de seu desenvolvimento ocorre ao final da $6^{\text {a }}$ semana de vida intrauterina (Lammert et al., 2003; Ellis e Auclair, 2008; Patel e Hoffman, 2014). 
As glândulas submandibulares são o segundo maior par de glândulas salivares humanas e podem pesar de 8 a 15 gramas. Estão situadas no triângulo submandibular por trás e por baixo da borda livre do músculo milohioídeo. Seu ducto se abre a cada lado do freio lingual através do conduto de Wharton (Berkovitz et al., 1992; Ferraris e Munõz, 2006; Holmberg e Hoffman, 2014).

Essas glândulas são tubuloacinares seromucosas, pois possuem, diferente das parótidas, ácinos mistos (mucosos e serosos) de proporção estimada 1:10, respectivamente, embora esta proporção possa ser diferente de lóbulo para lóbulo. Os ácinos serosos possuem grânulos de secreção abundantes com núcleo esférico e citoplasma basófilo. Já os ácinos mucosos são preenchidos com grânulos de secreção e pouca quantidade de citoplasma, além de núcleo comprimido contra a membrana plasmática (Ferraris e Munõz, 2006; Ten Cate, 2013; Holmberg e Hoffman, 2014).

Os ductos intercalares do parênquima submandibular são mais curtos quando comparados aos da parótida, desta forma aparecem menos numerosos. Os ductos estriados são mais ramificados e longos (Ferraris e Munõz, 2006; Katchburian e Arana, 2014).

A comunicação nervosa ocorre via nervo facial e ramos linguais do nervo mandibular e do tronco simpático, advinda do gânglio submandibular (Katchburian e Arana, 2014).

As glândulas submandibulares contribuem de forma substancial para a quantidade de saliva secretada no interior da cavidade oral. Secretam uma saliva mais viscosa composta por glicoproteínas sulfatadas, cistatinas e outras proteínas, além de identificados fatores de crescimento neural e epidérmico (que na mucosa oral podem favorecer a cicatrização de feridas) (Sivakumar et al., 2003; Ferraris e Munõz, 2006).

As células mucosas das glândulas submandibulares humanas podem apresentar uma heterogeneidade histológica de acordo com diferentes estágios de maturação (Ferraris e Munõz, 2006). 


\subsubsection{GLÂNDULA SUBLINGUAL}

A glândula sublingual humana inicia o desenvolvimento entre a $7^{\mathrm{a}}$ e $8^{\mathrm{a}}$ semana de vida embrionária (Ellis e Auclair, 2008).

Com peso médio de 3 gramas, é a menor dentre as principais glândulas salivares. Localizam-se profundamente entre tecido conjuntivo do assoalho da boca e o músculo milo-hioídeo. Não é considerada somente um par de glândulas já que, de cada lado, existem sistemas ductais próprios para glândula maior e várias unidades menores. Envolvidas por uma cápsula delicada, são um conjunto de glândulas muito próximas ligadas a um estroma comum (Ferraris e Munõz, 2006; Katchburian e Arana, 2014).

As glândulas sublinguais tem predomínio de células acinares mucosas. Nesta glândula, ácinos puramente serosos são exíguos (Berkovitz et al., 2002; Ferraris e Munõz, 2006; Ten Cate, 2013; Holmberg e Hoffman, 2014; Katchburian e Arana, 2014).

Abrindo-se na carúncula sublingual muito próximo ao conduto de Wharton das submandibulares, o conduto excretor de Bartholin é o principal ducto da glândula sublingual. Ainda, abrindo-se ao lado do freio lingual, há uma quantidade de condutos excretores acessórios de unidades glandulares menores. Seus ductos intercalares são muito curtos, portanto, difíceis de serem identificados em preparados histológicos (Ferraris e Munõz, 2006; Ten Cate, 2013; Holmberg e Hoffman, 2014). 


\subsection{GLÂNDULAS SALIVARES MENORES}

As glândulas salivares menores humanas iniciam seu desenvolvimento no 3ํㅡㄹ me gestação (Ellis e Auclair, 2008).

De modo paradoxal, as glândulas salivares menores são consideradas as mais importantes por terem componentes protetores em sua composição salivar (Edgar, 1990). Localizadas na mucosa ou submucosa do interior da cavidade bucal, exceto nas gengivas e porção anterior e média do palato duro, essas glândulas também recebem o nome de glândulas salivares secundárias, intrínsecas ou acessórias. Estruturalmente, as glândulas salivares menores são pequenas unidades formadas por grupos de ácinos rodeadas de tecido conjuntivo e não por uma cápsula definida como ocorre nas outras glândulas (Ferraris e Munõz, 2006; Katchburian e Arana, 2014).

Neste tipo glandular, nem sempre é possível identificar condutos intercalares ou estriados e os ductos excretores são relativamente curtos, abrindo-se diretamente sobre a superfície da mucosa e secretando a saliva provinda de agregados glandulares individuais (Ferraris e Munõz, 2006; Ten Cate, 2013).

As glândulas linguais de Von Ebner, localizadas na base das papilas valadas da língua possuem somente ácinos serosos. Essas glândulas são importantes na digestão de lipídeos do leite materno, sendo sua função essencial no recém-nascido. A inervação dessas glândulas é predominantemente do tipo parassimpático (Ferraris e Munõz, 2006; Ten Cate, 2013; Katchburian e Arana, 2014).

Representando cerca de $10 \%$ da secreção diária, a salivação contínua das glândulas salivares menores exercem papel crucial no mecanismo de proteção da mucosa oral e da superfície do esmalte, através da formação de uma película capaz de recobrir os dentes. Produzem por volta de $70 \%$ das mucinas salivares e quantidades importantes de $\operatorname{lgA}$, fosfatase ácida salivar e 
lisozimas, que impedem a colonização de microorganismos na superfície dental por causarem sua aglutinação, prevenindo assim, a ocorrência de cáries (Ferraris e Munõz, 2006; Ten Cate, 2013).

As glândulas salivares menores são afetadas pela ação de álcool, drogas, má nutrição entre outros, da mesma maneira que as glândulas salivares maiores. Por serem de fácil acesso, representam um menor risco em caso de necessidade de biópsia sendo, portanto, muito utilizadas em estudos e diagnósticos fisiológicos e fisiopatológicos (Ferraris e Munõz, 2006).

\subsection{As células componentes das glândulas salivares}

\subsection{1 ÁCINOS}

Os ácinos ou adenômeros são porções secretoras das glândulas salivares. Circundadas por células mioepiteliais, são responsáveis pela produção e secreção de saliva primária ao lúmen central. Os dois principais tipos de ácinos são os serosos e mucosos (Berkovitz et al., 1992).

Células serosas e mucosas diferenciam-se quanto aos componentes macromoleculares que produzem e secretam, bem como em sua estrutura. Ácinos serosos possuem pouca expressão de glicoconjugados que podem apresentar atividade antimicrobiana, enzimática e ligação com cálcio, além de grande quantidade de íons e água. A porção secretora acinar serosa é composta por 8 a 12 células de formato piramidal e ampla base subjacente ao estroma. Sua estrutura esférica se forma ao redor de um lúmen central de ápice estreito que, de forma geral, apresenta canalículos intercelulares capazes de aumentar a extensão luminal superficial. Os núcleos esféricos localizam-se 
no citoplasma basal. Células binucleadas são possíveis nesse tipo celular. $O$ armazenamento de componentes macromoleculares da saliva são encontrados em grandes quantidades nos grânulos de secreção localizados no citoplasma apical (Berkovitz et al., 1992; Ten Cate, 2013).

Ácinos mucosos formam uma porção secretora terminal tubulosa com núcleos achatados e comprimidos contra a superfície celular basal. Contém ampla quantidade de mucina como seu principal produto, acumulado em grânulos no citoplasma apical, além de glicoconjugados. A mucina secretada por esse tipo de ácino tem como principal função agregar-se a microorganismos formando uma barreira protetora de superfície, além de lubrificação da cavidade oral (Munger, 1964; Ellis e Auclair, 2008; Ten Cate, 2013; Proctor, 2016).

Algumas glândulas salivares menores bem como porções secretoras terminais mucosas de glândulas salivares maiores possuem, anexo ao ácino, uma porção serosa em forma de semilua na extremidade do túbulo, a semilua serosas ou ácino seromucoso. Por meio de canalículos intercelulares, estendem-se na extremidade tubular por entre as células mucosas e sua secreção atinge o lúmen, alcançando assim, o interior da cavidade oral (Berkovitz et al, 1992; Ten Cate, 2013).

\subsubsection{DUCTOS}

A rede ductal das glândulas salivares tem como função auxiliar a passagem da saliva da porção acinar até a cavidade oral, além de participação ativa no processo de produção e modificação da saliva primária para saliva secundária. As três classes de ductos são o intercalado, ducto estriado e ducto 
excretor, sendo que o diâmetro tubular aumenta de forma progressiva (Ten Cate, 2013).

Conectado diretamente aos ácinos, as células do ducto intercalado são a primeira porção ductal a receber a saliva ainda considerada primária, produzida pelas células acinares interligando-se ao restante dos ductos. Portanto, 0 lúmen da porção secretora é contínuo ao lúmen do ducto intercalar e seu comprimento é diferente entre glândulas salivares maiores e menores. Esta porção é parcialmente coberta por células mioepiteliais e sua estrutura é formada por células do epitélio simples cúbico, muitas vezes ocultas entre ácinos e ductos nas glândulas salivares menores, devido ao seu pequeno tamanho e ausência de características distintas. Possui núcleos centrais e pequena quantidade de citoplasma onde pode-se verificar a presença de pequenos grânulos de secreção na região apical, a qual possui pequenos microvilos projetando-se para dentro do lúmen. Esses grânulos possuem componentes como lisozima e lactoferrina, que são secretados na saliva (Berkovitz et al., 1992; Sato e Miyoshi, 1998; Ten Cate, 2013).

A mais importante e maior porção do sistema ductal é constituída pelo ducto estriado, o qual recebe a saliva primária do ducto intercalado. Localizados em meio aos lóbulos glandulares, é considerado um ducto intralobular. É a porção especializada na regulação da secreção e reabsorção de eletrólitos, com a importante função de modificação da saliva primária para secundária, sendo este o segundo na rede ductal com transporte bi-direcional entre o lúmen e os espaços extracelulares. Suas células são colunares e seu núcleo é central ao citoplasma. A região citoplasmática apical pode conter grânulos de secreção onde há presença de calicreína e pode haver a presença de outras proteínas plasmáticas, bem como vesículas, o que sugere a possibilidade de participação celular na endocitose de substâncias a partir do lúmen ductal. Possui numerosas mitocôndrias alongadas e dobramentos na superfície basolateral da membrana plasmática, daí o termo "estriado" (Berkovitz et al., 1992; Proctor \& Carpenter, 2007; Ten Cate, 2013).

Finalmente, o ducto excretor interlobular ou extralobular (devido sua localização entre os lóbulos glandulares), é responsável pela continuação da 
reabsorção de sódio e secreção de potássio e é o ultimo na rede de ductos, atingindo a mucosa da cavidade oral por onde a saliva é secretada. Possui epitélio pseudoestratificado, podendo tornar-se estratificado próximo á desembocadura da mucosa oral, além de vários tipos de células colunares epiteliais onde microvilos luminais consideradas de alguma forma como células receptoras, podem estar envolvidos no fluxo salivar ou em sua sensibilidade, reabsorção e secreção. Filamentos de actina com prolongamentos alongados semelhantes aos da célula mioepitelial podem se encontrar nas células basais desse ducto em alguns casos. Células dendríticas ou apresentadoras de antígenos também são encontradas (Berkovitz et al., 1992; Sato e Miyoshi, 1998; Ten Cate, 2013).

A modificação ductal da saliva primária para secundária, realizada pelos ductos estriados e excretores, bem como seu transporte, realizado também através do ducto intercalado, são cruciais para a secreção de uma saliva hipotônica ao interior da cavidade oral (Ten Cate, 2013).

\subsubsection{CÉLULAS MIOEPITELIAIS}

As células mioepiteliais estão presentes na unidade secretora acinar, interpostas entre ácinos e a membrana basal de muitas glândulas exócrinas de mamíferos, como nas glândulas salivares, mamárias, sudoríparas e lacrimais. Nos achados imunoistoquímicos encontram-se filamentos intermediários de queratina, considerado de origem epitelial e que também contém miofilamentos representando uma volumosa expressão de proteínas contráteis como actina, caldesmona, calponina e miosina, proteínas de músculo liso (Redman, 1994; lanez et al., 2010; Ogawa, 2003; Chitturi et al., 2015).

Sua distribuição varia de forma considerável entre os tipos de glândulas e mesmo durante o curso do desenvolvimento glandular. Tamarin em 1966 a descreveu "como um polvo sentado em uma rocha". Na porção terminal das 
glândulas salivares, as células mioepiteliais "abraçam" os ácinos. Ainda não há, na literatura, um consenso sobre a localização específica das células mioepiteliais. Em uma análise qualitativa de glândulas salivares, identificou-se células mioepiteliais ao redor dos ácinos mucosos e serosos e em diferentes regiões do sistema ductal (Hardy e Kramer, 1998).

As células mioepiteliais são associadas à funções de contração. Elas se contraem auxiliando na expulsão da saliva através de compressão e fortalecimento das células do parênquima glandular. Também possuem função na produção da membrana basal, além de contribuir para supressão de tumores e transporte de metabolitos. Acredita-se que estas células sejam originadas de células precursoras, porém, esta hipótese não esta totalmente elucidada (Redman, 1994; Hardy \& Kramer, 1998; lanez et al., 2010; Chitturi et al., 2015).

A detecção citoquímica de colinesterase e a presença de junções de hiato ultramicroscopicamente, apoiam a hipótese de que a células mioepiteliais têm um papel na propagação de estímulos neurais, também considerada uma de suas funções, apesar de não comprovado (Chitturi et al., 2015).

\subsection{SUPRIMENTO NERVOSO DAS GLÂNDULAS SALIVARES}

A composição e o volume de saliva secretada dependem de estimulação neural e a secreção normal está associada oo sistema nervoso autônomo. Neste cenário, o nervo parassimpático tem uma grande importância.

O sistema nervoso parassimpático, que está intimamente associad ao desenvolvimento da glândula salivar de fases precoces, é essencial à morfogênese de ramificação e iniciação de formação luminal. O sistema nervoso simpático, em contraste, não está associado às fases posteriores uma vez que a estrutura ramificada tenha se formado. À este passo, coincide-se a 
expansão do espaço luminal e diferenciação dos ácinos e estruturas ductais. 0 papel do sistema nervoso simpático durante o desenvolvimento da glândula salivar, no entanto, não está totalmente elucidado. Foi demonstrado que o fator de crescimento neural (NGF) tem um papel chave na regulação do neurônio simpático em outros sistemas e esta via é expressa nas glândulas salivares humanas. (Ghasemlou et al., 2004; Proctor e Carpenter, 2007; Knox et al., 2010; Datta et al., 1991; Naesse et al., 2013; Nedvetsky et al., 2014)

Proctor e Carpenter (2007) e Proctor (2016), em sua excelente revisão, demonstraram que o reflexo da secreção de saliva é mediada por nervos autonômicos em glândulas salivares adultas. A estimulação parassimpática provoca um aumento no volume de saliva, enquanto que a estimulação simpática interfere em uma secreção rica em proteínas. Os receptores M1 e M3 muscarínicos interagem com acetilcolina nos nervos parassimpático levando à secreção de fluidos, enquanto os nervos simpáticos são ativados pela noradrenalina e $\beta 1$ adrenérgicos a secreção de proteínas (Asking e Gjörstrup, 1987; Proctor, 2016).

Quase todos os tipos de células de glândulas salivares parecem ser inervado por ambos, os nervos simpáticos e parassimpático. A inervação colinérgica no sistema vascular ocorre em todas as glândulas salivares. Nos vasos sanguíneos glandulares, a inervação simpática provoca vasoconstrição, porem, não ocasiona nenhum efeito no reflexo salivar (Rossoni et al, 1981;. Garret, 1987; Proctor e Carpenter, 2007).

Alguns receptores como mecanorreceptores, receptores olfativos, receptores gustativos e nociceptores induzem a secreção de saliva através do reflexo de estimulo, como a mastigação, paladar e outros estímulos. A ativação de alguns diferentes mecanorreceptores localizados no ligamento periodontal e mucosas, onde estão o epitélio dos botões de paladar no dorso da língua, evocam a secreção salivar nas glândulas salivares maiores. Este aumento do fluxo também pode ocorrer nas glândulas salivares menores em resposta à estímulo de paladar (Shannon et al., 1969; Speirs, 1984; Hector e Linden, 1999). 


\subsection{SUPRIMENTO SANGUÍNEO DAS GLÂNDULAS SALIVARES}

A artéria carótida externa oferece suprimento sanguíneo à parótida, já a glândula submandibular tem acesso à vascularização arterial via ramos da artéria lingual (Katchburian e Arana, 2014).

Capilares provindos de arteríolas estendem-se ao redor das porções secretoras terminais e dos ductos estriados. Essas arteríolas são originadas por uma ou mais artérias que penetram na glândula e dividem-se em arteríolas menores encontradas também ao redor dos ductos excretores. O fluxo sanguíneo é capaz de aumentar em até 15 vezes durante o período de secreção máxima (Ten Cate, 2013).

Apesar de o papel da vasculatura durante o desenvolvimento glandular embrionário permanecer sem elucidação, o suprimento vascular das glândulas salivares é crucial para se manter o fluido necessário de forma que a secreção salivar seja mantida (Patel et al., 2006; Ten Cate, 2013; Liu e Wang, 2014).

\subsection{SALIVA}

O principal componente salivar é a água (Ishikawa et al., 2006).

A saliva é um complexo fluido biológico, essencial à preservação da imunidade e homeostase oral através da manutenção da lubrificação e proteção dos dentes, proteção contra invasão de organismos potencialmente patogênicos, neutraliza a ação dos ácidos agindo como solução de tamponamento, auxilia no paladar, mastigação e deglutição dos alimentos, 
proporcionando conforto e bem estar ao organismo humano com particular importância à cavidade oral. O epitélio de superfície da mucosa oral é considerado escamoso estratificado queratinizado ou não queratinizado e fornece proteção mecânica contra atividade microbiana, além de danos químicos (Dale et al., 1990; Edgar, 1992; Humphrey e Williamson, 2001; Tiwari, 2011; Patel e Hoffman, 2014)

Produzida e secretada pelos três principais pares de glândulas salivares, além das glândulas salivares menores distribuídas no interior da cavidade oral, a saliva é composta por mais de $99 \%$ de água, além de uma variedade de eletrólitos que incluem sódio, potássio, magnésio, cálcio, fosfatos e bicarbonato, amônia e ureia como produtos nitrogenados, proteínas, enzimas, imunoglobulinas e mucinas. A secreção salivar acontece em dois estágios. Em um primeiro momento, a saliva produzida por células acinares é isotônica (saliva primária), tornando-se um fluido hipotônico (saliva secundária), durante sua passagem pelo sistema ductal. $O$ ducto intercalar, que está ligado diretamente ao ácino, não participa da transição salivar de isotônica para hipotônica, visto que nesse ramo do ducto não há alterações ou troca de eletrólitos. É no ducto estriado que o sódio e cloro são reabsorvidos para que, já na porção final, as células do ducto excretor permaneçam reabsorvendo sódio e secretem $\mathrm{K}^{+}$e $\mathrm{HCO}_{3}{ }^{-}$à saliva final, antes que esta seja lançada à cavidade oral já em sua forma hipotônica (Roth e Calmes, 1981; Garret, 1987, Edgar, 1992, Sreebny, 2000; Humphrey e Williamson, 2001; Turner e Sugiya, 2002; Melvin et al., 2005; Proctor e Carpenter, 2007; Hsu e Yamada, 2010; Lee et al., 2012; Delporte, 2013; Ferreira e Hoffman, 2013)

As membranas apicais e basolaterais das células secretoras são capazes de gerar a osmose em resposta a um gradiente transepitelial de íons promovendo assim, a secreção salivar (Ishikawa e Ishida, 2000).

De forma mais minuciosa, a transformação da saliva isotônica para hipotônica ocorre da seguinte maneira:

Primeiramente, as células acinares secretam um fluido isotônico que passa do ducto intercalar ao ducto estriado. As células do ducto estriado 
modificam a secreção acinar primária reabsorvendo $\mathrm{Na}^{+}$e $\mathrm{Cl}^{-}$, o que indica que a formação da saliva é principalmente realizada pelo transporte transepitelial de $\mathrm{Cl}^{-}$e que, a absorção de $\mathrm{Cl}^{-}$é dependente do $\mathrm{Na}^{+}$dirigido para dentro do gradiente através da membrana plasmática basolateral. Um aumento no $\mathrm{Ca}^{2+}$ intracelular, normalmente associado ao estímulo de receptores muscarínicos, provoca secreção do fluido ativando simultaneamente os canais de $\mathrm{Cl}^{-}$apicais e canais basolaterais de $\mathrm{K}^{+}$. Em um segundo momento, ainda nas porções de ducto estriado e excretor, ocorre a secreção de $\mathrm{K}^{+}$e $\mathrm{HCO}_{3}{ }^{-}$, resultando em uma saliva final hipotônica. Em células acinares da glândula salivar, a secreção está associada com mudanças de volume celular. $O$ encolhimento e inchaço das células acinares seguem estímulos de receptores muscarínicos e $\beta$ adrenérgicos, que ocorrem como resultado de um desequilíbrio entre o influxo e efluxo de íons (especificamente $\mathrm{Cl}^{-}$), entre a membranas basolaterais e luminais. O resultado na mudança de tonicidade requer uma rápida e regulada alteração na permeabilidade, resultando em um gradiente osmótico transepitelial, dirigindo o movimento da água e criando uma secreção semelhante à secreção primária. Quando a saliva atinge o interior da cavidade oral ela é considerada hipotônica. (Foskett e Melvin, 1989; Foskett, 1990; Turner et al., 1993; He et al., 1997; Steward et al., 1998; Delporte, 2013).

Exemplos das trocas iônicas que ocorrem durante a formação da saliva estão ilustrados na Figura 7. 


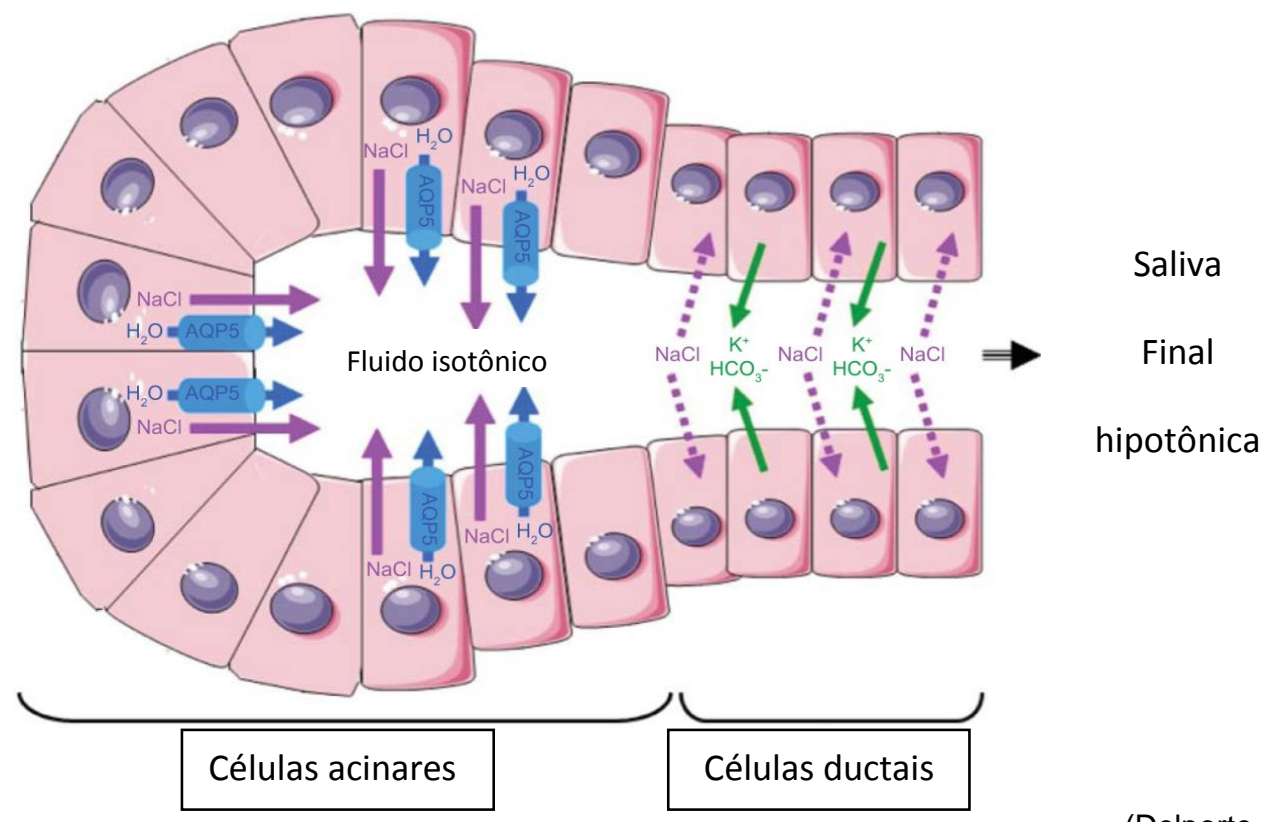

(Delporte, 2013)

Figura 7: Estrutura acinar no processo de transformação da saliva primária para secundária. Na primeira etapa, a secreção salivar, um fluido isotônico rico em $\mathrm{NaCl}$ é secretado pelas células acinares. $\mathrm{Na}$ segunda etapa, ocorre troca iônica nas porções do ducto estriado e excretor onde $\mathrm{Na}^{+}$e $\mathrm{Cl}^{-}$são reabsorvidos ${\mathrm{e} \mathrm{HCO}_{3}}^{-}$e $\mathrm{K}^{+}$são secretados, resultando em uma saliva final hipotônica ao atingir a cavidade oral.

Além do ciclo circadiano, onde uma menor taxa de fluido salivar acontece durante os períodos de sono, há também um ciclo anual interferente no fluxo e concentração de componentes salivares (eletrólitos e proteínas). Durante o verão, o fluxo salivar diminui, enquanto seu pico ocorre no inverno (Dawes, 1974; Edgar, 1990; Rudney, 1995).

A média salivar diária é de $750 \mathrm{ml}$ a 1 litro. A saliva é ligeiramente ácida e possui pH entre 6,0 e 7,0 podendo variar de 5,3 em baixo fluxo salivar até 7,8 em pico de fluxo. Relata-se ainda, que o fluxo salivar pode diminuir de acordo com o aumento da idade, ocorrendo em menor quantidade em pessoas idosas (Edgar, 1990; Catalán et al., 2009).

A diminuição da saliva ou xerostomia pode ser causada, por doenças como a Síndrome de Sjögren, efeito adverso de medicações, radiação para 
tratamento de câncer de cabeça e pescoço, entre outros, podendo acarretar em perda da saúde oral com a ocorrência de cáries, doença periodontal severa, infecções persistentes, além de causar dificuldades para mastigar, engolir e falar (Hsu e Yamada, 2010).

Muitas áreas de pesquisa já avaliam as funções e componentes salivares no diagnóstico, tratamento e prevenção de doenças locais e sistêmicas. Seu valor incontestável no fornecimento de diversos tipos de informações continua crescendo também pelo fato de ser um fluido facilmente coletável, com um processo não invasivo (Humphrey e Williamson, 2001).

O movimento de água entre as membranas celulares é fundamental para a produção salivar e este tipo de transporte é realizado com o auxílio de proteínas de canais de membrana denominadas aquaporinas (Kozoko et al., 2002).

\subsection{AQUAPORINAS}

A água é o principal componente de todas as células vivas constituindo cerca de $70 \%$ da massa corpórea. Sua distribuição e eficiente regulação através de movimentos intercelulares é necessária a muitos processos biológicos. Para isso, uma família de proteínas de canais de membrana denominadas aquaporinas auxiliam o transporte de água (Kozono et al., 2002; Matsuzaki et al., 2004; Agre, 2006; Kruse et al., 2006; Papadopoulos et al., 2008).

Descoberta por Agre e colaboradores no final dos anos 80 , as aquaporinas fazem parte da família das proteínas integrais de membrana que formam canais envolvidos no transporte de água e outros pequenos solutos entre membranas celulares, em resposta a um gradiente osmótico ou gradiente 
de concentração representado por difusão facilitada (Agre et al., 1987; Krane et al., 2001; Kozono et al., 2002; Agre, 2009; Abscal et al., 2014; Mobasheri e Barret-Jolley, 2014).

As aquaporinas possuem estruturas muito similares e estão presentes em diferentes tecidos. Sua permeabilidade contribui para muitos eventos fisiológicos por sua regulação precisa no transporte de água, eletrólitos e outros solutos, sendo nas glândulas salivares elemento crucial à produção salivar (Mulders et al., 1995; Krane et al., 2001; Kozono et al., 2002).

As proteínas aquaporinas (AQP's) são os canais de água mais abundantes em uma variedade de células que transportam fluidos (Figura 8). Treze membros da família AQP foram identificados até o momento nas células de mamíferos ( $A Q P 0$ à $A Q P 12)$. Estas proteínas são divididas em três subgrupos: as aquaporinas (AQP0, AQP1, AQP2, AQP4, AQP5, AQP6, AQP8) permeáveis somente à água, as aquagliceroporinas (AQP3, AQP7, AQP9 e AQP10), permeáveis à agua e pequenos solutos como glicerol e ureia, além de ter papel no metabolismo energético e no transporte de metais pesados. As aquaporinas 11 e 12 podem ser denominadas superaquaporinas ou aquaporinas não clássicas, pois sua permeabilidade à água ou pequenos solutos é incerta (Borgnia et al., 1999; Agre et al., 2002; Agre, 2004; Morishita et al., 2004; Hara-Chikuma e Verkman, 2006; Yool, 2007; Rojek et al., 2008; Musa-Aziz et al., 2009; Ishibashi et al., 2011; Ishibashi et al, 2014, Zhu et al., 2015). 


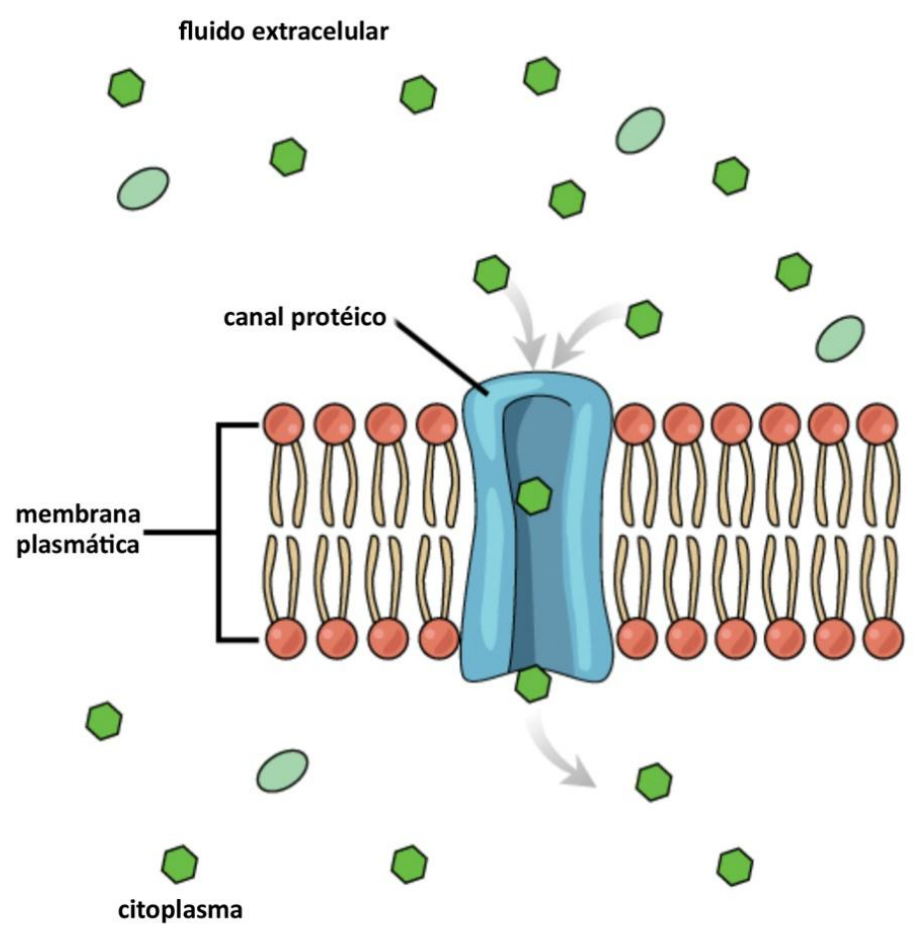

Fonte: https://www.boundless.com/biology/textbooks/boundless-biology-textbook/structure-and-function-of-plasmamembranes-5/passive-transport-65/facilitated-transport-332-11469/

Figura 8: Esquema ilustrando abertura de passagem entre os meios extra e intracelular da bicamada fosfolipídica da membrana plasmática através da aquaporina.

Recentes avanços na determinação estrutural das aquaporinas ao nível atômico tem revelado a chave de mecanismos pelos quais estes canais mantém uma impressionante seletividade sem sacrificar altas taxas de transporte. Alguns estudos preveem um modelo "ampulheta" para estrutura das aquaporinas (Jung et al., 1994; Kozono et al., 2002).

Com peso molecular de 28-32 kDa, as proteínas aquaporinas possuem seis domínios transmembrânicos e cinco voltas intracelulares $(A-E)$. As voltas $B$ a E contém uma alta e conservada característica ou sinal Asn-Pro-Ala (NPA), que estão profundamente incorporados na membrana lipídica bilateral formando um poro aquoso. Cada monômero age como um poro aquoso individual, resultando de sua associação tetrâmera, e cada isoforma de AQP é 
composta por uma única cadeia de peptídeo de 270 aminoácidos (Figura 9) (Preston e Agre, 1991; Smith e Agre, 1991; Jung et al., 1994; Walz et al., 1997; Agre, 2004; Kruse et al., 2006)

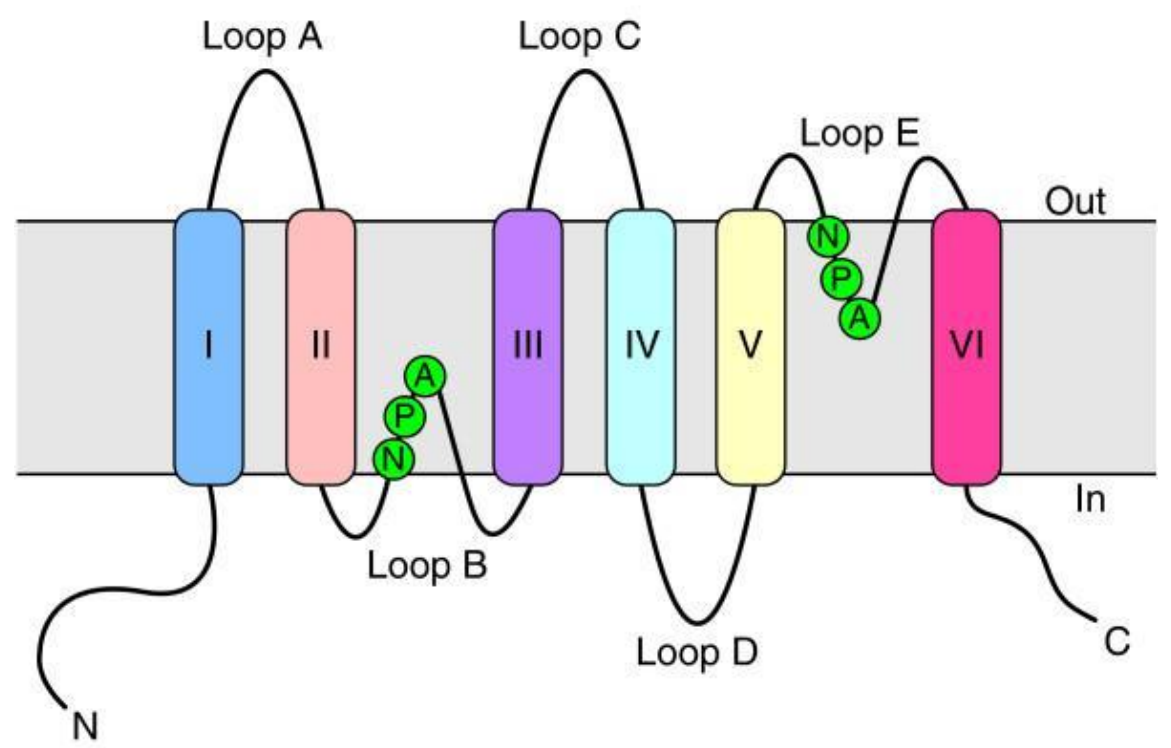

(Kruse et al, 2006)

Figura 9: Topologia de uma proteína aquaporina no interior da bicamada fosfolipídica da membrana plasmática. A proteína consiste de seis hélices transmembranares $(\mathrm{I}-\mathrm{VI})$ conectados por cinco ciclos (AE). Em lados opostos, C, terminal carboxilo; N, no terminal amino.

Evidencia-se a facilitação da migração celular através das aquaporinas. Mais investigações podem revelar que os sinais estruturais levam a diferenças em muitos aspectos em suas funções como base para oligomerização, propriedades na permeabilidade de canal, estabilidade e movimentação (Kozono et al., 2002; Papadopoulos et al., 2008).

As aquaporinas aumentam a permeabilidade da membrana celular plasmática à agua em 5 à 50 vezes mais, quando comparada a membranas onde a água move-se primariamente através do lipídio bilateral (Verkman, 2005) 
Suspeita-se que as aquaporinas possam estar envolvidas em numerosos danos a sistemas e órgãos que envolvem o transporte de fluidos como a angiogênese em vasos sanguíneos da metástase tumoral, glaucoma, edema cerebral, pre-eclâmpsia, cirrose, falha cardíaca congestiva e outros eventos que necessitem de agilidade no movimento celular dirigido. Existem também, evidências de migração celular em fenômenos biológicos como a angiogênese, regeneração de órgãos, cicatrização de feridas, entre outros (Kozono et al., 2002; Saadoun et al., 2005; Papadopoulos et al., 2008).

A elucidação das bases moleculares do mecanismo de controle das aquaporinas pode levar ao entendimento do movimento da água entre as membranas biológicas no que diz respeito à doenças. Portanto, conhecer a estrutura das aquaporinas pode facilitar o planejamento do uso racional de medicamentos e promover percepções que levem à visão de doenças causadas por diferentes mutações em um único gene, objetivando uma nova terapêutica e promovendo assim, resoluções farmacológicas. Agentes que auxiliam no bloqueio de canais de água podem ser úteis em estados de sobrecarga de fluidos como diuréticos (King e Agre, 1996)

Em mecanismos fisiopatológicos de tumores, observa-se o aumento da expressão das aquaporinas em muitos tipos de câncer. Inibir a ação das aquaporinas pode modular os eventos de propagação de células neoplásicas. A descoberta deste potencial faz com que estas proteínas sejam novo objeto anti-tumoral para desenvolvimento molecular objetivando a terapêutica para o câncer (Papadopoulos et al., 2008; Huang et al., 2013; Mobasheri e BarretJolley, 2014; Shan et al., 2014).

As aquaporinas 1,3 e 5 têm sido amplamente identificadas nas glândulas salivares de mamíferos (King e Agre, 1996; Ma e Verkman, 1999; Ishikawa e Ishida, 2000; Beroucas et al., 2001; Gresz et al., 2001; Krane et al., 2001; Verkman, 2002; Akamatsu et al., 2003; Matsuzaki et al., 2004; Delporte e Steinfeld, 2006; Ishikawa et al., 2006; Kruse et al., 2006; Gresz et al., 2015) e, baseando-se nessas evidências, investigamos neste trabalho a expressão das aquaporinas 1 , 3 e 5 . 


\subsubsection{AQUAPORINA 1 (AQP1)}

O primeiro indício da existência das aquaporinas ocorreu pela identificação de proteínas, até então desconhecidas, purificadas de eritrócitos, uma célula altamente permeável à água. Denominada CHIP28 e posteriormente aquaporina 1, esta foi a primeira proteína da família aquaporina a ser descrita (Smith e Agre, 1991; Preston et al., 1992, Agre et al, 1993).

A aquaporina 1 é amplamente distribuída nas células endoteliais de capilares e pequenos vasos sanguíneos por todo o corpo, realizando o transporte transendotelial, com exceção ao sistema nervoso central. Particularmente nas glândulas salivares, a expressão de AQP1 já foi descrita em modelos animais e humanos, sendo encontrada tanto em componentes do estroma e do parênquima glandular. Outros estudos mostram a expressão desta aquaporina também nas células ductais e mioepiteliais (Gresz et al., 1999; Gresz et al., 2001; Verkman, 2002; Matsuzaki et al., 2004; Verkman, 2006; Akamatsu et al, (2003) identificaram a presença de AQP1 em vasos sanguíneos e capilares na glândula submandibular de ratos durante todo 0 período de desenvolvimento embrionário.

Estudos sugerem que o crescimento e a propagação de tumores estejam possivelmente relacionados com a atividade dos canais de água, indicado pela observação de aumento de expressão de AQP1 em células tumorais malignas. Com a deleção do gene desta aquaporina em ratos, observou-se redução da angiogênese, da migração celular endotelial e limitação no crescimento de tumores na agiogênese. A expressão da aquaporina 1 em células tumorais facilita sua infiltração e, consequentemente, seu potencial metastático de modo que a inibição deste canal pode reduzir o crescimento tumoral (Saadoun et al., 2005; Papadopoulos et al., 2008). 
O papel funcional de AQP1 nas células endoteliais ainda não está elucidado, mas evidências indiretas aceitam a ideia de que esta proteína tenha papel na formação e função de pequenos vasos sanguíneos. Em hemácias, há uma baixa taxa de permeabilidade de $\mathrm{CO}_{2}$ através dos canais de AQP1, e sua estrutura dinâmica demonstra características que facilitam o rápido transporte de água. Dados sugerem que a AQP1 também não exerça função crucial na secreção salivar. Além das glândulas salivares, a AQP1 também está presente no ducto biliar, sistema ductal pancreático, rins, e fígado (Terashima e Ono, 2002; Saadoun et al., 2002; Matsuzaki et al., 2004; Saadoun et al., 2005; Delporte e Steinfeld, 2006; Gregoire et al., 2015).

\subsubsection{AQUAPORINA 3 (AQP3)}

A aquaporina 3 é uma aquagliceroporina, o que indica que além de água, esta proteína possui características únicas que a permitem mediar 0 transporte de glicerol, ureia e outros pequenos solutos (Matsuzaki et al., 2004; Hara-Chikuma e Verkman, 2008). Esta aquaporina foi identificada nas membranas basolaterais das células acinares serosas e mucosas das glândulas salivares em humanos adultos e ratos. Sua expressão, no entanto, não foi confirmada em células ductais (Gresz et al., 2001; Beroukas et al., 2002; King et al., 2004).

Na pele, a AQP3 tem função crucial por mediar o transporte de glicerol como elemento para suas funções básicas e sua deficiência pode acarretar diminuição de elasticidade e hidratação. Também demonstra aumento na migração e proliferação de queratinócitos, com implicações terapêuticas na cicatrização de feridas. Sua expressão também é citada nas córneas, cólon, ânus, rins e pulmões, com especial intensidade no epitélio do trato digestivo 
superior e cavidade oral (Ma et al., 2002; Matsuzaki et al., 2004; Hara-Chikuma e Verkman, 2008, Papadopoulos et al., 2008; Verkman et al., 2008).

A AQP3 é inativada em baixo $\mathrm{pH}$, porém sua expressão é aumentada por hipertonicidade e hiperosmolaridade. É possível que uma das funções desta proteína seja contribuir para o movimento fluido transepitelial da lâmina própria (Zeuthen e Klaerke, 1999; Matsuzaki et al., 2001; Matsuzaki et al., 2004). Além disso, sugere-se que a aquaporina 3 tenha papel determinante no crescimento tumoral devido aos altos índices desta AQP encontrados em amostras de câncer gástrico e evidencias de ativação de vias de sinalização tumoral (Chen et al., 2014; Zhou et al., 2016).

\section{9 .3 AQUAPORINA 5 (AQP5)}

A aquaporina 5 é um canal de água específico encontrado nas células secretoras de tecidos glandulares como as glândulas salivares, sudoríparas e lacrimais, glândulas submucosas das vias respiratórias, estômago, duodeno, epitélio brônquico e pneumócitos tipo I do trato respiratório, além de epitélio da córnea e vias aéreas e do pâncreas. Possibilita a regulação da permeabilidade transcelular, bem como permeabilidade paracelular, exercendo importante função na secreção de fluidos, além da migração e proliferação celular (King e Agre, 1996; Ishikawa et al., 1998; Matsuki et al., 2005; Ishikawa et al., 2006; Sidhaye et al., 2012; Huang et al., 2013).

Muitos estudos relatam a expressão de diferentes aquaporinas nas glândulas salivares humanas e em modelos animais, mas a aquaporina 5 tem um papel central no processo de regulação da secreção do fluido salivar (Beroukas et al., 2001; Akamatsu et al., 2003; Larsen et al., 2011; Saito et al., 2015), visto que deleções da proteína AQP5 prejudicam a secreção de fluidos 
da glândula salivar (Ma et al., 2000). Após o nascimento, quando já existe estímulo de secreção salivar, a AQP5 foi encontrada nas membranas luminais, laterais e basais das células acinares (Aure et al., 2011; Larsen et al., 2011).

Sendo esta aquaporina o principal meio de regulação da permeabilidade de água através das membranas celulares dos ácinos das glândulas salivares, a AQP5 determina as taxas de fluxo e composição iônica da saliva secretada. A regulação do volume das células acinares durante a secreção salivar é um processo dinâmico influenciado por estímulos muscarínicos e $\alpha$-adrenérgicos, resultando respectivamente em tumefação e encolhimento celular. Também é descrito que o envolvimento nervoso do sistema parassimpático nas células acinares submandibulares, e $\beta$-adrenérgico na glândula parótida, interferem nos níveis de aquaporina 5. Os mecanismos de integração nervosa das glândulas salivares durante o período de desenvolvimento glandular salivar ainda não estão totalmente elucidados (Proctor e Carpenter, 2007; Krane et al., 2001; Hosoi, 2016).

A utilização da técnica de imunoistoquímica é eficiente para demonstração de expressão de AQP5. A recuperação antigênica é um passo essencial na exposição de epítopos e, consequente, imunomarcação das glândulas salivares adultas humanas. Deste modo, é possível observar a distribuição de APQ5 nas membranas apicais, basolaterais e citoplasma das células acinares, e citoplasma ductal, tecido conjuntivo em torno de ácinos e ductos das glândulas salivares humanas, além do citoplasma das células epiteliais ductais. (Beroukas et al, 2001, Gresz et al., 2001). A expressão de AQP5 também tem sido detectada nas células acinares de ratos, camundongos e outras espécies animais durante o desenvolvimento embrionário. Estudos recentes demonstram padrões de transcrição e expressão de AQP5, bem como sua distribuição espaço temporal nas diversas fases do desenvolvimento de glândulas salivares submandibulares de ratos (Krane et al., 2001; Aure et al., 2011; Larsen et al., 2011). 
4. MATERIAIS E MÉTODOS 


\section{MATERIAIS E MÉTODOS}

Espécimes de glândulas salivares dissecadas de embriões/fetos humanos em diferentes estágios gestacionais (14 à 25 semanas), provenientes da Divisão de Anatomia Patológica do HC-FMUSP foram utilizados (Figura 10). Ao todo, 47 espécimes de 20 fetos diferentes foram submetidos à técnica de imunoistoquímica. Todos os fetos obtidos para dissecção foram oriundos de abortos espontâneos e pesavam menos de 500 gramas, sendo considerados peças cirúrgicas. As idades gestacionais dos fetos foram determinadas por meio da medida plantar segundo MCBride et al, (1984), no momento da dissecção. Todos os espécimes foram fixados em formalina tamponada a 10\% e emblocados em parafina para realização da técnica de imunoistoquímica.

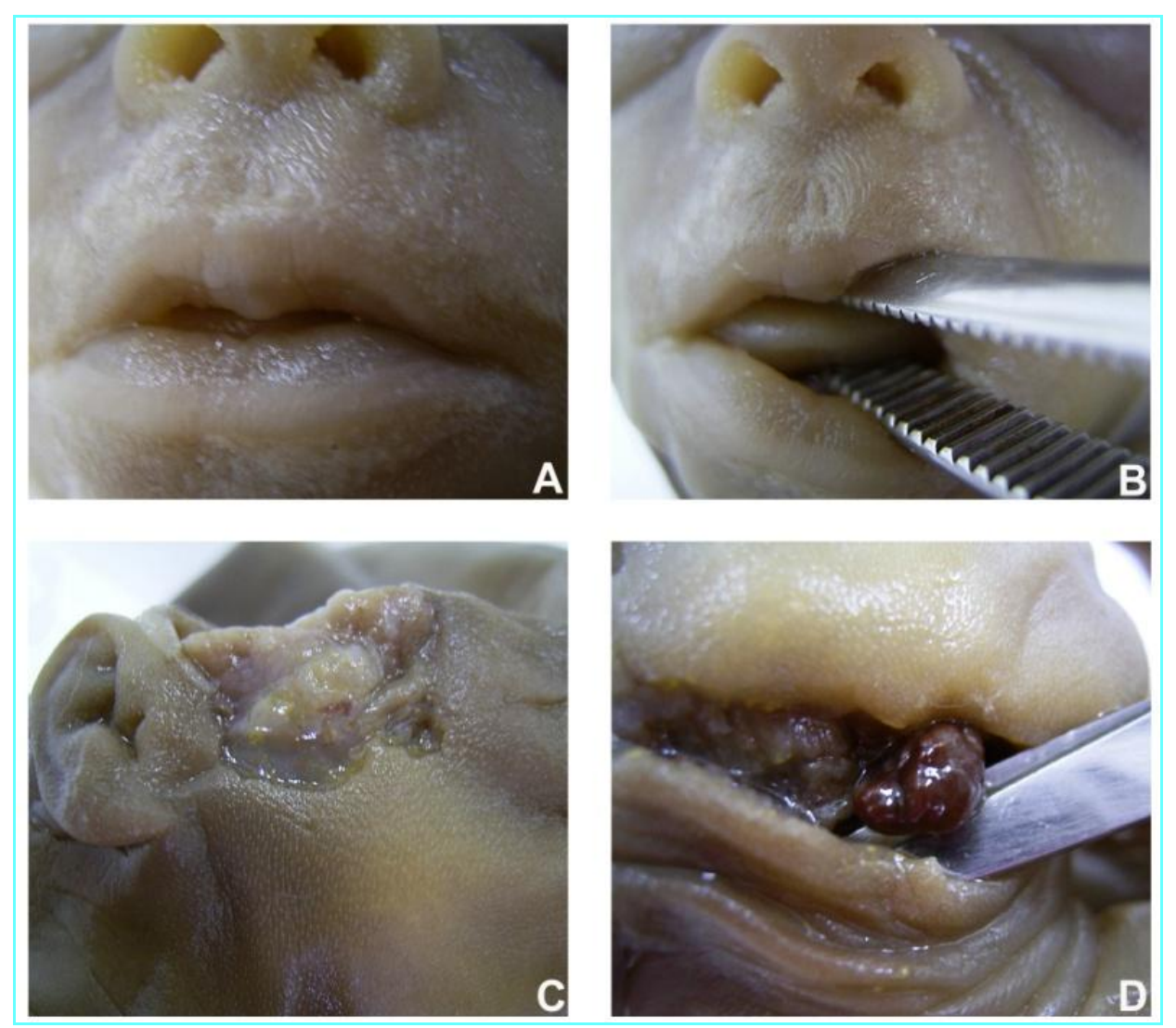

Figura 10: Dissecção das glândulas salivares nos fetos humanos. A: Lábio; B: Língua; C: Glândula parótida; D: Glândula submandibular. 


\subsection{Critérios de inclusão}

Espécimes de estruturas orofaciais de fetos humanos que
apresentavam, ao exame microscópico, estruturas identificadas como
glândulas salivares nos seus diversos estágios de morfodiferenciação.

\subsection{Critérios de exclusão}

Espécimes dissecados de fetos humanos que não apresentavam estruturas glandulares ou que, ao exame microscópico apresentavam estruturas maceradas e com a morfologia prejudicada pelo processamento histológico.

\subsection{Imunoistoquímica}

Cortes de $3 \mu \mathrm{m}$ dos espécimes selecionados - parótida, submandibular e glândulas salivares menores do palato, assoalho, mandíbula, lábio e língua, foram inicialmente desparafinizados em três banhos de xilol: o primeiro a $60^{\circ} \mathrm{C}$ por 30 minutos, o segundo e o terceiro a temperatura ambiente por 7 minutos cada. A seguir os cortes foram reidratados em cadeia descendente de etanol (2 banhos de 2 minutos cada em etanol 100\%, 2 banhos de 2 minutos cada em 
etanol 95\% respectivamente) e imersos em solução de hidróxido de amônia a 10\% durante 10 minutos para a remoção de pigmentos formólicos. Após lavagem em água corrente po 5 minutos e água destilada por 5 minutos, a recuperação dos epítopos antigênicos foi realizada com tampão citrato $\mathrm{pH}$ 6,0 em steamer por 45 minutos. Após esse período, as lâminas passaram por tempo de resfriamento (20 minutos), em temperatura ambiente.

Após a lavagem em água corrente e água destilada, foi realizada a incubação do material em solução de peróxido de hidrogênio 10 volumes, 2 banhos por 10 minutos cada, com o intuito de bloquear a peroxidase endógena tecidual. Repetida a lavagem com água corrente e água destilada, os cortes foram imersos duas vezes em solução Tris $\mathrm{HCl} \mathrm{pH} \mathrm{7,4} \mathrm{por} \mathrm{cinco} \mathrm{minutos} \mathrm{cada.}$ Em seguida, os cortes foram incubados em leite Molico a 10\% diluído em PBS $\mathrm{pH} 7,4$ por 30 minutos com intuito de bloquear eventuais proteínas inespecíficas. As informações sobre os anticorpos e a concentração de cada um deles estão descritas na tabela 1. Os procedimentos posteriores foram sempre precedidos de duas lavagens em solução Tris $\mathrm{HCl}$ pH 7,4.

Após a incubação com o anticorpo primário em período overnight, os espécimes foram incubados com anticorpo secundário sistema Novolink ${ }^{\circledR}$ em 2 etapas de 30 minutos cada.

Para a reação de revelação, os espécimes foram incubados com 0 revelador permanente diaminobenzidina - DAB (Dako Cytomation ${ }^{\circledR}$ ) - por 3 minutos, que evidencia a reação por meio de coloração acastanhada. Os cortes foram posteriormente lavados em água corrente e água destilada e contracorados com hematoxilina de Carazzi por 5 minutos. Posteriormente, foram montados em resina permount ${ }^{\Theta}$ para o exame ao microscópio de luz.

Os controles negativos das reações supracitadas foram realizados por meio da incubação de espécimes com soro não-imune, e os positivos pertinentes foram incluídos de acordo com as especificações de cada anticorpo. 


\begin{tabular}{|c|c|c|c|c|c|}
\hline $\begin{array}{c}\text { Soro } \\
\text { primário }\end{array}$ & Clone/código & Título & $\begin{array}{l}\text { Controle } \\
\text { positivo }\end{array}$ & Procedência & $\begin{array}{c}\text { Recuperação } \\
\text { antigênica }\end{array}$ \\
\hline AQP1 & $\begin{array}{l}\text { Mouse } \\
\text { monoclonal } \\
\text { ab9566 }\end{array}$ & $1: 500$ & Rim & Abcam & $\begin{array}{c}\text { Citrato pH } \\
6,0- \\
\text { Steamer }\end{array}$ \\
\hline AQP3 & $\begin{array}{c}\text { Rabbit } \\
\text { policlonal } \\
\text { ab153694 }\end{array}$ & $1: 1000$ & Rim & Abcam & $\begin{array}{c}\text { Citrato pH } \\
6,0- \\
\text { Steamer }\end{array}$ \\
\hline AQP5 & $\begin{array}{c}\text { Rabbit } \\
\text { monoclonal } \\
\text { ab92320 }\end{array}$ & $1: 900$ & $\begin{array}{c}\text { Glândula } \\
\text { salivar }\end{array}$ & Abcam & $\begin{array}{c}\text { Citrato pH } \\
6,0- \\
\text { Steamer }\end{array}$ \\
\hline
\end{tabular}

Tabela 1: Dados dos anticorpos primários utilizados no estudo em glândulas salivares humanas, com respectivos clones e códigos, titulações utilizadas, controles, procedências e modo de recuperação antigênica.

Todos os resultados foram analisados qualitativamente, de acordo com a fase do desenvolvimento glandular, levando-se em conta a topografia das aquaporinas estudadas. Os resultados foram fotografados com equipamento fotográfico digital acoplado a microscópio óptico Olympus. 
5. RESULTADOS 


\section{RESULTADOS}

A análise qualitativa dos espécimes incluídos no estudo revelaram a presença de glândulas salivares nas diversas estruturas dissecadas. Essas glândulas apresentavam-se nos diversos estágios de sua morfogênese, seguindo a classificação de Tucker, 2007. A idade dos fetos utilizados foi variável, entretanto, observamos que em um mesmo tempo de idade gestacional, observavam-se glândulas salivares em estágios morfogenéticos distintos. Baseados nesses achados, os resultados aqui descritos irão se basear nos aspectos fenotípicos das glândulas salivares, de acordo com o seu estágio de desenvolvimento e não na idade fetal.

\subsection{Análise imunoistoquímica}

\subsubsection{Aquaporina 1 (AQP1)}

Houve expressão da proteína aquaporina 1 em todas as fases da morfogênese glandular salivar humana (Figura 11). $O$ resultado da imunoexpressão dos tipos celulares estão descritos na tabela 2.

Em todos as fases onde espécimes de glândulas salivares fetais humanas com idade entre 14 e 25 foram submetidos ao teste de imunoistoquímica, a aquaporina 1 exibiu relevante expressão em capilares e vasos sanguíneos. 
Pôde-se observar que, durante o período de morfogênese das glândulas salivares humanas, algumas células mioepiteliais expressaram aquaporina 1, ao passo que outras não obtiveram imunomarcação. Além disso, alguns espécimes de glândula submandibular também não expressaram AQP1, independente de sua fase de desenvolvimento ou idade fetal.

Não houve expressão desta proteína nas porções dos ductos estriados e excretores em nenhuma das fases da morfogênese glandular salivar humana.

\section{ESTÁGIO BOTÃO INICIAL}

Nesta fase, observamos acentuada e difusa expressão de aquaporina 1 nos primórdios acinares. Foi possível identificar intensa expressão desta proteína nas membranas basolaterais.

\section{ESTÁGIO PSEUDOGLANDULAR.}

O citoplasma dos primórdios acinares permaneceram expressando aquaporina 1 de forma difusa. A expressão da aquaporina 1 nas membranas basolaterais continuou sendo observada de forma acentuada.

\section{ESTÁGIO CANALICULAR}

Observamos leve diminuição de expressão citoplasmática e as porções de membrana basolateral permaneceram expressando aquaporina 1 de forma acentuada.

\section{ESTÁGIO DE BOTÃO TERMINAL}

Nesta fase não houve expressão aquaporina 1 no citoplasma e membranas basolaterais. Esta proteína foi observada nas porções de ducto intercalar em alguns espécimes e em porções organizadas das células pró- 
acinares, do que se presume serem células mioepiteliais. Na maior parte dos espécimes, somente os ductos intercalares de fases mais desenvolvidas expressaram aquaporina 1. 


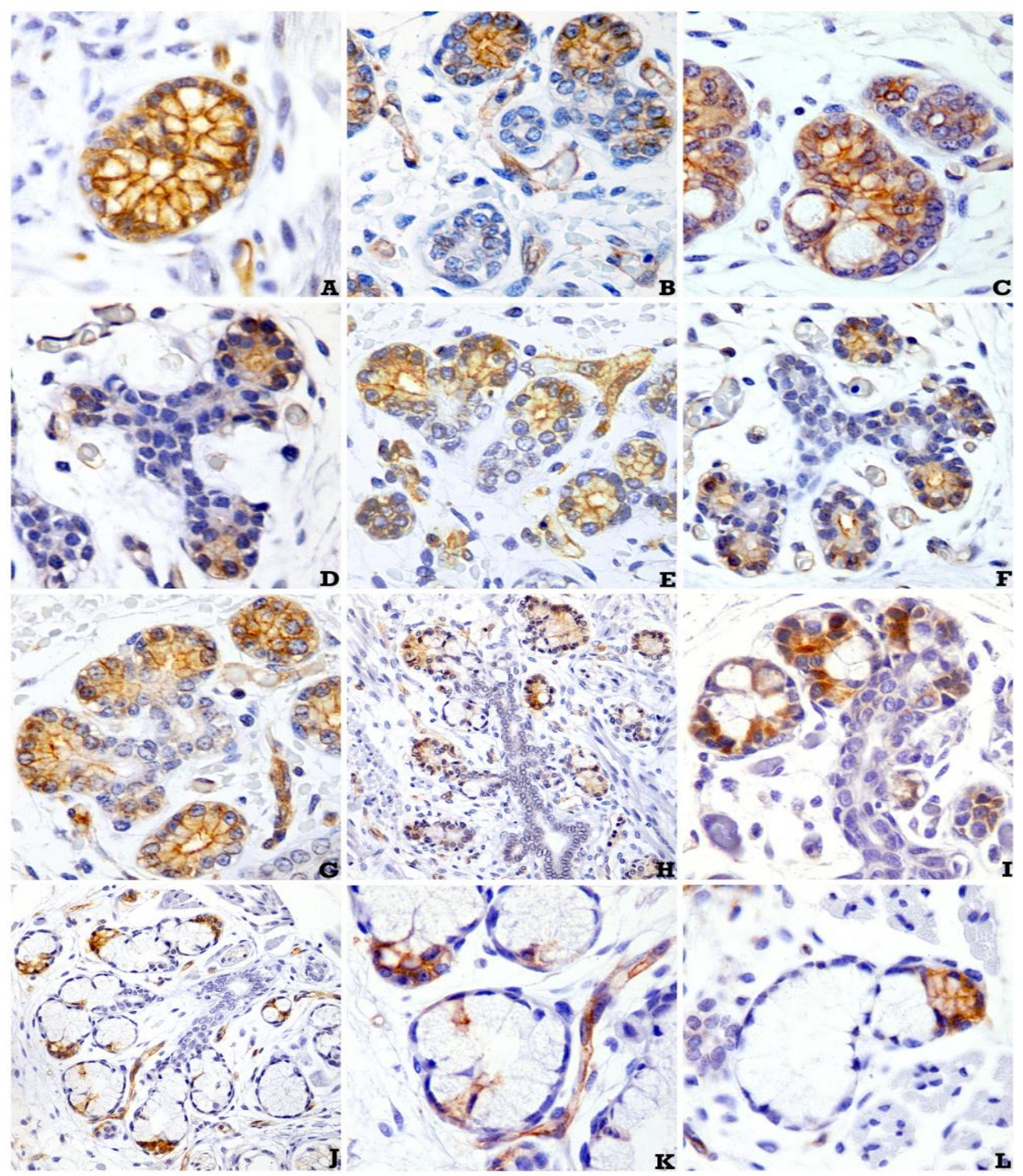

Figura 11: Expressão da proteína aquaporina 1 durante o desenvolvimento das glândulas salivares de fetos humanos. A/B/C - ESTÁGIO BOTÃO INICIAL: intensa expressão de aquaporina 1 nas membranas basolaterais dos primórdios acinares, com difusa e acentuada expressão citoplasmática. Pequenos capilares no estroma também são positivos para expressão de AQP1; D/E/F ESTÁGIO PSEUDOGLANDULAR: O citoplasma pré-acinar permanece expressando aquaporina 1 de forma difusa. A expressão da aquaporina 1 permanece nas membranas basolaterais de forma acentuada. Células do endotélio expressam AQP1; G/H/I - ESTÁGIO CANALICULAR: as porções pré-acinares expressam aquaporina 1 nas membranas basolaterais. Em alguns ácinos, observa-se diminuição de expressão citoplasmática. Possíveis células mioepiteliais (Imagem I) também são positivas para esta proteína. Capilares sanguíneos são positivos para aquaporina 1; J/L - ESTÁGIO DE BOTÃO TERMINAL: Nesta fase, células do ducto intercalar e de vasos sanguíneos apresentam aquaporina 1. $\mathrm{Na}$ imagem $\mathbf{K}$, além de ductos intercalares, é possível observar células presumidamente mioepiteliais expressando esta proteína. Células endoteliais do tecido de sustentação expressam AQP1 de forma intensa. Magnificação original: A/C/K/L 630x; B/D/E/F/G 400x; H/J200x. 


\subsubsection{Aquaporina 3 (AQP3)}

Houve expressão da proteína aquaporina $3 \mathrm{em}$ todas as fases da morfogênese glandular salivar humana (Figura 12). $O$ resultado da imunoexpressão dos tipos celulares estão descritos na tabela 2.

Em todos os espécimes onde o epitélio pôde ser verificado, houve intensa expressão de aquaporina 3. Isto ocorre devido à região epitelial da mucosa oral ser considerada uma extensão da pele, onde esta proteína expressa-se nos queratinócitos.

Não houve expressão de aquaporina 3 em vasos sanguíneos e capilares, células mioepiteliais e ductos estriados e excretores em nenhuma das fases da morfogênese glandular salivar humana.

\section{ESTÁGIO BOTÃO INICIAL}

Rudimentos acinares expressaram aquaporina 3 de forma difusa no citoplasma. A expressão desta proteína foi também identificada em estruturas membranares basolaterais forma intensa.

\section{ESTÁGIO PSEUDOGLANDULAR}

Observou-se intensa expressão citoplasmática de aquaporina 3, porém, nesta fase, estruturas mais maduras expressaram esta proteína de forma menos acentuada. Neste estágio, a expressão da aquaporina 3 tornou-se mais organizada e acentuada nas estruturas membranares basolaterais e apicais. Nas estruturas onde pôde ser observada, AQP3 expressou-se de forma difusa e apicalmente nas estruturas pré-ductais. 


\section{ESTÁGIO CANALICULAR}

Identificamos intensa expressão da aquaporina 3 nas membranas basolaterais e apicais. No citoplasma pré-acinar, a expressão desta proteína foi observada de modo menos intenso quando comparada às fases anteriores, chegando a ser negativa em alguns espécimes. A região ductal evidênciou expressão de AQP3 de forma difusa e nas estruturas apicais.

\section{ESTÁGIO DE BOTÃO TERMINAL}

Nesta fase, o citoplasma das células pró-acinares apresentaram fraca positividade para a aquaporina 3. As membranas basolaterais das células próacinares expressam esta proteína de forma menos acentuada. Houve intensa expressão de aquaporina 3 nos ductos intercalares observados em todos os espécimes. 


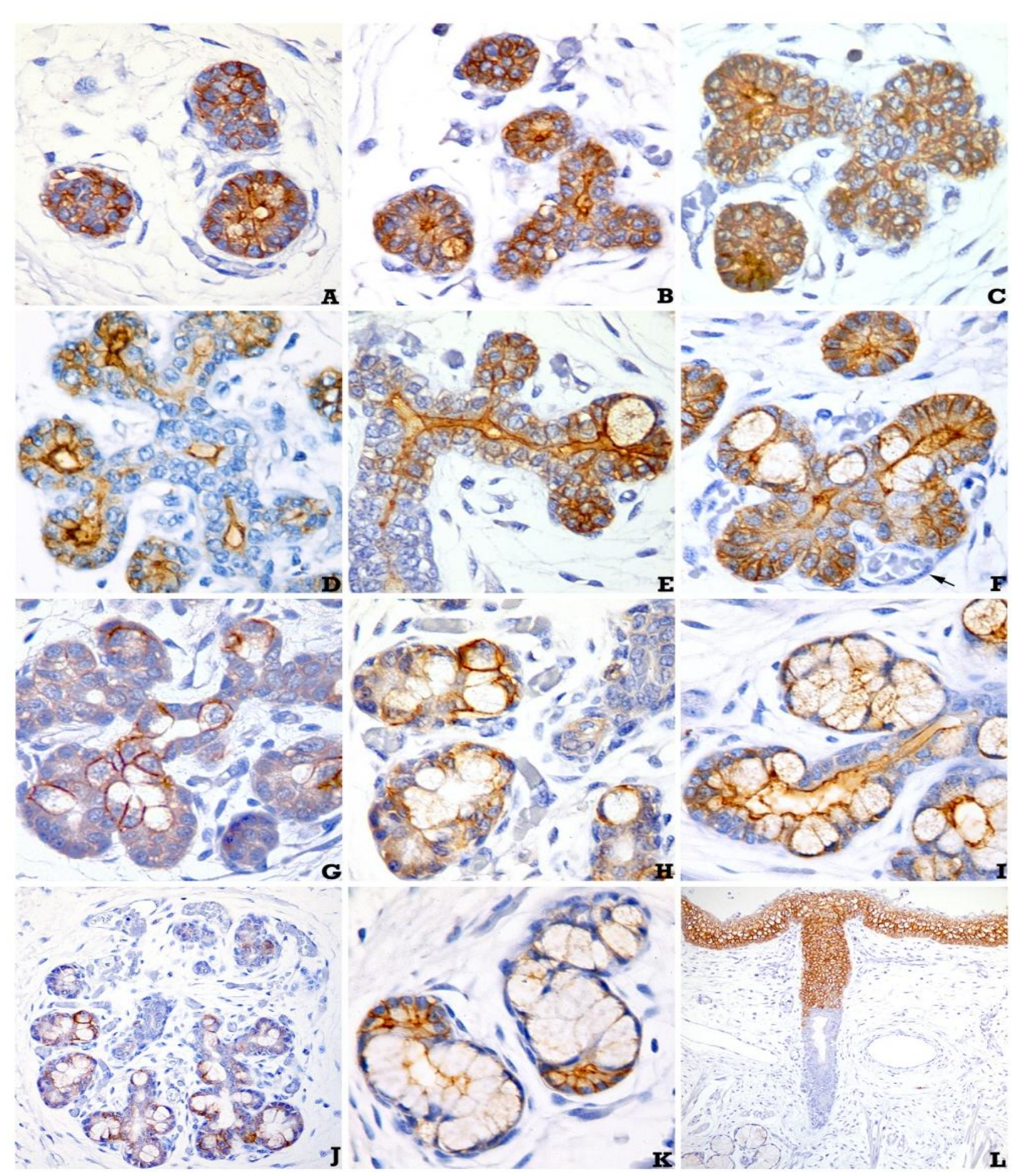

Figura 12: Expressão da proteína aquaporina 3 durante 0 desenvolvimento das glândulas salivares de fetos humanos. A/B/C - ESTÁGIO BOTÃO INICIAL: Células acinares rudimentares expressam aquaporina 3 de forma intensa nas membranas basolaterais e difusamente no citoplasma; D/E/F - ESTÁGIO PSEUDOGLANDULAR: A expressão citoplasmática é evidente, mas ocorre de forma menos acentuada em algumas estruturas mais desenvolvidas desta fase. A expressão da Aquaporina 3 nas membranas basolaterais é intensa, bem como na região apical rudimentar e pré-ductal; G/H/I - ESTÁGIO CANALICULAR: Observa-se expressão da aquaporina 3 nas membranas basolaterais e apicais. No citoplasma acinar, a expressão de aquaporina 3 é observada de modo menos intenso quando comparado às fases anteriores; J/K - ESTÁGIO DE BOTÃO TERMINAL: O citoplasma das células acinares apresentam positividade fraca para aquaporina 3. As membranas basolaterais das células pró-acinares expressam esta proteína de forma menos acentuada. Ductos intercalares evidenciam intensa expressão para aquaporina 3. L - Queratinócitos presentes no epitélio da mucosa demonstraram intensa positividade para esta proteína, mas o epitélio ductal é negativo. Magnificação original: A/B/C/D/E/F/G/H/I/K 630x; J/L 400x. 


\subsubsection{Aquaporina 5 (AQP5)}

Houve expressão da proteína aquaporina $5 \mathrm{em}$ todas as fases do desenvolvimento glândular salivar humano (Figura 13). O resultado da imunoexpressão dos tipos celulares estão descritos na tabela 2.

Não houve expressão de vasos sanguíneos e capilares, células mioepiteliais e ductos estriados e excretores nos espécimes analisados.

\section{ESTÁGIO DE BOTÃO INICIAL}

Nesse estágio as células epiteliais glandulares expressaram aquaporina 5 de forma intensa e difusa, com maior intensidade na membrana apical em espécimes onde esta estrutura já pode ser observada.

\section{ESTÁGIO PSEUDOGLANDULAR}

Observou-se acentuada e difusa expressão citoplasmática de aquaporina 5, além de expressão intensa desta proteína nas membranas basolaterais e apicais das estruturas pré-acinares. Nos espécimes onde foi possível identificar o início da abertura pré-ductal, a expressão de aquaporina 5 ocorreu nas membranas apicais e de forma difusa.

\section{ESTÁGIO CANALICULAR}

Nesta fase, o citoplasma de algumas estruturas pré-acinares expressaram aquaporina 5 de forma menos acentuada quando comparado às fases anteriores. As membranas apicais e basolaterais permaneceram expressando aquaporina 5 de forma evidente e acentuada. A região apical da 
abertura ductal expressou esta proteína de forma acentuada e algumas vezes difusa.

\section{ESTÁGIO BOTÃO TERMINAL}

Neste estágio, o citoplasma das células pró-acinares foi fracamente positivo para aquaporina 5 . As membranas basolaterais e apicais expressaram esta proteína de forma intensa sendo mais evidnete na membrana apical. As estruturas ductais intercalares expressaram aquaporina 5 de forma acentuada. 


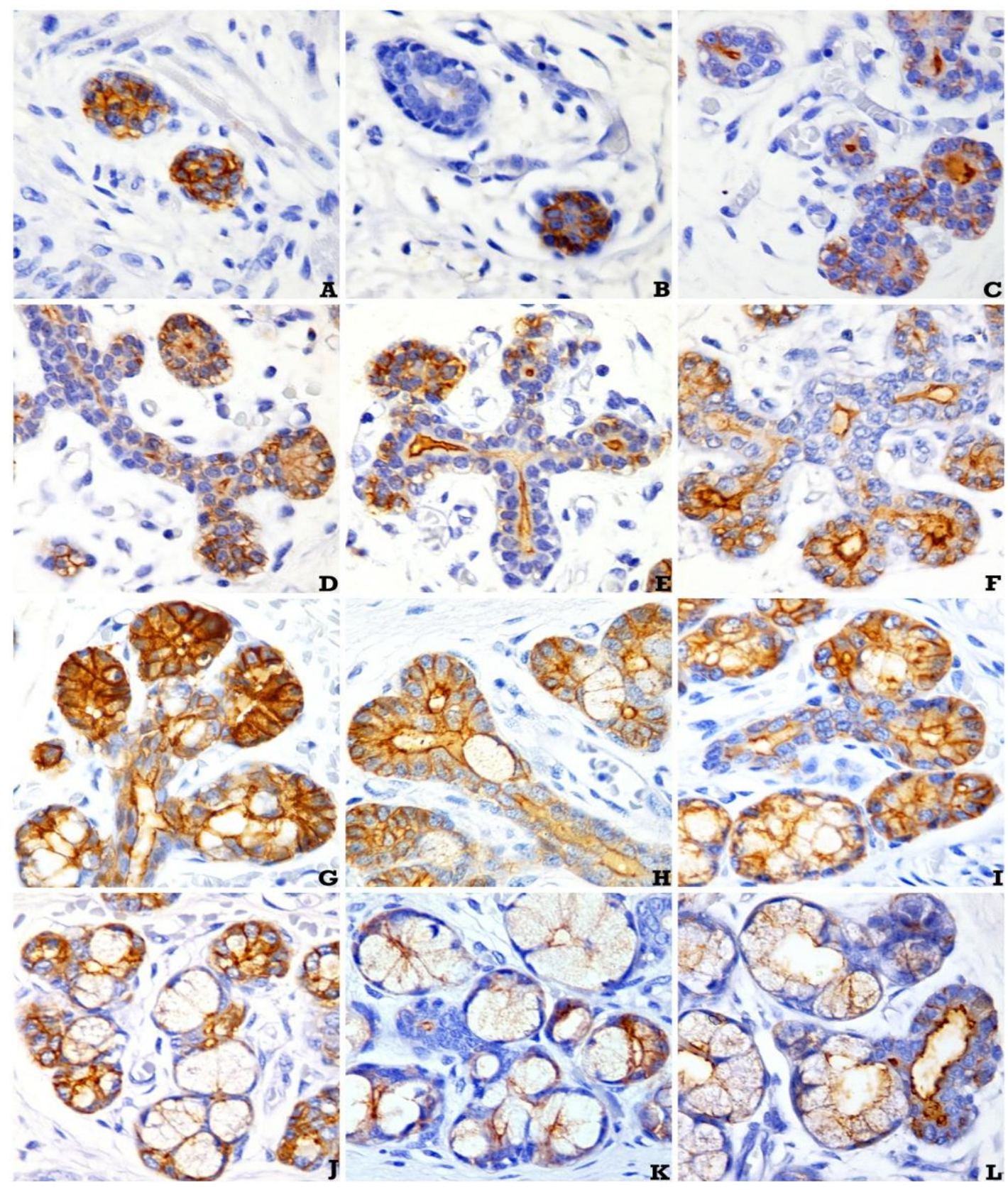

Figura 13: Expressão da proteína aquaporina 5 durante o desenvolvimento das glândulas salivares de fetos humanos. A/B/C - ESTÁGIO DE BOTÃO INICIAL: Rudimentos acinares expressam AQP5 de forma intensa e difusa; D/E/F - ESTÁGIO PSEUDOGLANDULAR: Expressão intensa da aquaporina 5 nas membranas basolaterais e apicais. O citoplasma de ácinos rudimentares expressam AQP5 de forma acentuada. Nos sítios onde abertura pré ductal é observada, a expressão de aquaporina 5 ocorre de nas membranas apicais e de forma difusa; $\mathbf{G} / \mathbf{H} / \mathbf{l}$ ESTÁGIO CANALICULAR: As membranas apicais e basolaterais de ácinos rudimentares expressam AQP5 de forma intensa. A região apical da abertura ductal expressa esta proteína de forma acentuada e algumas vezes difusa. $O$ citoplasma esta mais fracamente marcado em algumas estruturas; $\mathbf{J} / \mathbf{K} / \mathbf{L}$ ESGTÁGIO BOTÃO TERMINAL: As células pró-acinares do estágio de botão terminal apresentam intensa positividade para aquaporina 5 nas membranas basolaterais. As membranas apicais de ácinos e ductos expressam AQP5 de forma intensa e o citoplasma é fracamente marcado nesta fase. Na imagem $\mathrm{K}$ desta figura, é possível identificar um ducto intercalar expressando aquaporina 5 de forma intensa. Magnificação original: 630x. 


\begin{tabular}{|c|c|c|c|c|c|}
\hline \multirow{4}{*}{ 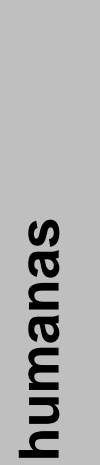 } & Estágios & Estruturas & AQP1 & AQP3 & AQP5 \\
\hline & \multirow{2}{*}{ Botão inicial } & $\begin{array}{c}\text { Ramificação dos cordões } \\
\text { epiteliais }\end{array}$ & + & + & + \\
\hline & & $\begin{array}{l}\text { Capilares e vasos } \\
\text { sanguíneos }\end{array}$ & + & - & - \\
\hline & \multirow{4}{*}{ Pseudoglandular } & $\begin{array}{l}\text { Células acinares } \\
\text { rudimentares }\end{array}$ & + & + & + \\
\hline \multirow{5}{*}{ 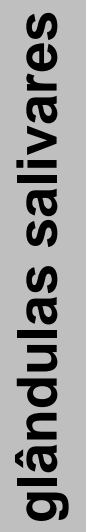 } & & Células ductais & - & + & + \\
\hline & & Células mioepiteliais & $-/+$ & - & - \\
\hline & & $\begin{array}{l}\text { Capilares e vasos } \\
\text { sanguíneos }\end{array}$ & + & - & - \\
\hline & \multirow{4}{*}{ Canalicular } & $\begin{array}{l}\text { Células acinares } \\
\text { rudimentares }\end{array}$ & + & + & + \\
\hline & & Células ductais & + & + & + \\
\hline$\frac{0}{0}$ & & Células mioepiteliais & $-/+$ & - & - \\
\hline \multirow{5}{*}{ 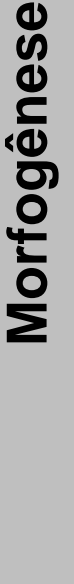 } & & $\begin{array}{l}\text { Capilares e vasos } \\
\text { sanguíneos }\end{array}$ & + & - & - \\
\hline & \multirow{4}{*}{ Botão terminal } & Células pró-acinares & - & + & + \\
\hline & & Células ductais & + & + & + \\
\hline & & Células mioepiteliais & $-/+$ & - & - \\
\hline & & $\begin{array}{l}\text { Capilares e vasos } \\
\text { sanguíneos }\end{array}$ & + & - & - \\
\hline
\end{tabular}

Tabela 2: Análise da expressão das aquaporinas nas diferentes fases do desenvolvimento fetal das glândulas salivares humanas. (+) Imunomarcação positiva; (-) Ausência de imunomarcação; (-/+) Imunomarcação indefinida. 
6. DISCUSSÃO 


\section{DISCUSSÃO}

O presente estudo mostrou a expressão das aquaporinas 1, 3 e 5 nas diversas fases do desenvolvimento e morfogênese das glândulas salivares humanas. Essas proteínas exercem a importante função de facilitar o transporte de água e pequenos solutos através da bicamada fosfolipídica da membrana plasmática, auxiliando na produção e secreção da saliva ao interior da cavidade oral. Dessa forma, investigamos e descrevemos os padrões de expressão imunoistoquímicos das aquaporinas 1, 3 e 5. Até o momento, não existem estudos das proteínas aquaporinas nas glândulas salivares de fetos humanos descritos, mas extensas revisões e trabalhos experimentais descrevem a presença das aquaporinas 1, 3 e 5 em glândulas salivares humanas adultas e em modelos animais adultos e em desenvolvimento, que em geral relataram resultados semelhantes aos nossos. (King e Agre, 1996; Ma e Verkman, 1999; Matsuzaki et al., 1999; Ishikawa et al., 2000; Beroucas et al., 2001; Gresz et al., 2001; Verkman, 2002; Akamatsu et al., 2003; King et al., 2004;; Larsen et al., 2009, 2011; Gresz et al., 2015).

Corroborando nossos achados, a expressão da aquaporina 1 foi identificada em células endoteliais, capilares e região basal acinar. Relatos em glândulas salivares de ratos demonstram que a aquaporina 1 expressa-se no pólo basal do citoplasma de ácinos rudimentares da glândula labial e também em ductos intercalares. A expressão de aquaporina 1 nas células mioepiteliais de glândulas salivares, apesar de não confirmada em nosso trabalho, é amplamente descrita na literatura (Beroucas et al., 2002; Gresz et al., 1999, 2001; Verkman, 2002; Akamatsu et al., 2003).

Nas glândulas salivares de fetos humanos em desenvolvimento utilizadas nesse trabalho, pôde-se observar que a expressão da aquaporina 1 ocorreu nas membranas basolaterais e difusamente distribuídas na região citoplasmática de estruturas glandulares acinares pouco desenvolvidas. Identificamos ainda, que durante as fases mais tardias do desenvolvimento 
somente células endoteliais e ductos intercalares imunoexpressam AQP1. A presença da aquaporina $1 \mathrm{em}$ pequenos capilares que circundavam os rudimentos acinares em desenvolvimento, sugere que o enovelamento de capilares e vasos sanguíneos seja imprescindível ao desenvolvimento acinar glandular. Akamatsu et al., (2003) identificaram importante expressão de mRNA de AQP1 em glândulas submandibulares de ratos em desenvolvimento por meio de RT-PCR, principalmente nas fases iniciais de desenvolvimento. Seus resultados imunoistoquímicos identificaram AQP1 somente em capilares e vasos sanguíneos, sendo ausente em ductos glandulares, sugerindo que a AQP1 seja fundamental na manutenção da estrutura glandular normal.

As glândulas salivares humanas adultas por sua vez, também expressaram AQP1 nas células endoteliais e mioepiteliais (Gresz et al., 2001). Além disso, o mesmo estudo identificou achados semelhantes aos nossos, em que se detectou uma pequena diferença no padrão de expressão da AQP1 entre os ácinos serosos da glândula parótida, que têm uma expressão mais intensa da proteína, e os ácinos mucosos das glândulas submandibular, sublinguais e labiais adultas. Relata-se ainda, que a região basal de ácinos e ductos intercalares também expressem aquaporina 1, porém discute-se que essa expressão ductal pode indicar, na verdade, a presença dessa proteína nas células mioepiteliais que envolvem estes ductos, não representando necessariamente uma expressão em células ductais (Gresz et al., 2001).

Durante todo o período de desenvolvimento glandular dos fetos humanos, os nossos resultados reveleram que a expressão da aquaporina 1 em células endoteliais do estroma foi evidente e intensa, corroborando diversos estudos descritos na literatura (Beroucas et al., 2002; Gresz et al., 1999, 2001; Verkman, 2002; Akamatsu et al., 2003). Algumas evidências indicam ainda que a AQP1 tenha papel na formação e função de microvasos (Saadoun et al., 2005).

Em nossos achados, alguns espécimes de glândulas parótidas expressaram aquaporina 1 em vasos sanguíneos e na região citoplasmática acinar rudimentar de forma difusa na fase inicial do desenvolvimento, particularmente nas membranas basolaterais e nas membranas apicais. 
Glândulas submandibulares da mesma idade gestacional, por sua vez, não demonstraram expressão de rudimentos acinares ou ductais. Questiona-se se esta diferença na expressão da aquaporina 1 ocorra devido à origem embrionária dos folhetos germinativos. Dessa forma, sugere-se que a glândula parótida humana tenha origem ectodermal, enquanto as glândulas submandibulares, sublinguais e glândulas salivares menores sejam originadas a partir do segundo folheto germinativo, o endoderma, representando portanto um possível motivo para a discrepância de expressão de AQP1 nas diferentes glândulas (Fitzgerald, 1980; Filho et al., 2002; Avery, 2002).

Larsen et al., (2009) realizaram trabalhos experimentais em glândulas salivares embrionárias de camundongos, demostrando expressão de mRNA das aquaporinas 1, 3 e 5, sugerindo que a presença dessas proteínas estejam envolvidas no processo de maturação glandular. Sugere também que essas aquaporinas estejam participando de processos de apoptose, adesão celular, osmose ou regulação do volume celular, proliferação, além de migração e transporte transepitelial.

Embora a aquaporina 1 seja amplamente descrita nas células mioepiteliais de glândulas salivares humanas e nossos resultados ilustrarem a imunomarcação de AQP1 em regiões que apresentam células mioepiteliais, este trabalho sugere que não seja possível concluir somente por meio de imunoistoquímica que as células positivas realmente representem esse tipo celular durante o período de morfogênese das glândulas salivares humanas. Nos espécimes submetidos aos testes de imunoistoquímica, a AQP1 expressou-se nos ductos intercalares de algumas amostras. Um estudo realizado por Beroukas et al., (2002) identificou a expressão de AQP1 nas células dos ductos intercalados das glândulas salivares de pacientes com Síndrome de Sjögren primária, porém, um estudo de Gresz et al., (2001) sugere a possibilidade desta imunomarcação ter ocorrido nas células mioepiteliais presentes neste ducto.

Estudos preliminares do nosso grupo revelam que algumas amostras submetidas à dupla marcação com APQ1 e marcador de actina de músculo liso (SMA), no entanto, não demonstraram co-localização dessas moléculas, 
indicando que AQP1 não se expresse nas células mioepiteliais das glândulas salivares.

Pouco se sabe sobre a importância da expressão e atividade da AQP1 durante processos morfogenéticos, porém já se relatou o aumento da expressão da aquaporina $1 \mathrm{em}$ neoplasias malignas. Isso indica um possível papel regulador para os canais de água no crescimento e disseminação tumoral, mostrando que essa proteína é importante não só nos processos de embriogênese, mas também na manutenção de estruturas normais e em processos patológicos (Saadoun et al., 2005).

Corroborando nossos estudos, a aquaporina 3 é identificada, segundo os dados da literatura, de forma intensa na região mucosa da cavidade oral, especificamente na membrana plasmática das células do epitélio escamoso estratificado, expressando-se também nas membranas basolaterais das células acinares de glândulas salivares humanas adultas e modelos animais em desenvolvimento e após o nascimento. (Matsuzaki et al., 1999; Gresz et al., 2001; Beroucas et al, 2002, Akamatsu et al., 2003). Na mucosa epitelial da cavidade oral e ânus, a expressão da AQP3 ocorre por continuação da epiderme (Matsuzaki et al., 2004).

Gresz et al., (2001) identificaram a expressão de AQP3 nas membranas basolaterais de ácinos mucosos e serosos de glândulas salivares humanas adultas por meio da técnica de imunoistoquímica, mas não nas membranas apicais das células acinares e ductos intercalados. Nossos resultados ilustraram que, além de expressão das membranas basolaterais, a expressão da AQP3 no ducto intercalado e nas membranas apicais de ácinos de glândulas salivares de fetos humanos também foi evidente em todas as fases do desenvolvimento. A expressão ductal da aquaporina 3 ainda não havia sido descrita nas glândulas salivares. Gresz et al., (2001) observaram ainda, a expressão da proteína aquaporina 3 mais abundante em ácinos serosos que em ácinos mucosos das glândulas submandibulares, porém essa diferença não foi observada em nossos experimentos.

Nossos achados corroboram ainda, resultados descritos por Beroucas et al., (2002) e Baker et al., (2010), que identificaram intensa expressão de AQP3 
nas membranas basolaterais acinares em glândulas parótidas de ratos e em células acinares de glândulas salivares humanas adultas. Akamatsu et al., (2003) e Larsen et al., (2009) identificaram ainda a expressão de mRNA de aquaporina 3 nas glândulas salivares de ratos em desenvolvimento. Larsen et al., (2009) sugerem que a aquaporina 3 exerça o papel mais importante durante os estágios iniciais do processo de desenvolvimento glandular salivar. Em nossos achados, observamos que glândulas salivares humanas em desenvolvimento expressaram aquaporina 5 de forma tão acentuada quanto aquaporina 3 em todas as fases do desenvolvimento, ressaltando a importância de mais investigações comparativas entre os modelos humano e animal.

Ainda não está elucidada a forma como aquaporina 5 se distribui nas glândulas salivares durante o desenvolvimento embrionário (Larsen et al., 2011).

A principal proteína responsável pela regulação da permeabilidade de água através da membrana plasmática das células acinares de glândulas salivares é a AQP5, que determinará a composição iônica e as taxas de fluxo salivar secretado (Krane et al., 2001). Em acordo com essa hipótese e também corroborando nossos resultados, a expressão de aquaporina 5 foi amplamente descrita em glândulas salivares adultas e de ratos em desenvolvimento e após o nascimento. Morfologicamente e por meio de diferentes técnicas, a aquaporina 5 foi encontrada na região apical acinar, em membrana basolateral e citoplasma das células acinares, incluindo canalículos e grânulos secretores intercelulares, além de ser encontrada em ductos intercalares (He et al., 1997; Ma et al., 1999; Matsuzaki et al., 1999; Beroucas et al., 2001, 2002; Gresz et al., 2001, 2015; Ishikawa et al., 2000, 2006; Krane et al., 2001; Akamatsu et al., 2003; Matsuki et al., 2005; Larsen et al., 2009, 2011; Aure et al., 2011; Sidhaye et al., 2012; Sugimoto et al., 2013; Peters et al., 2014). Das estruturas de glândulas salivares de fetos em desenvolvimento que puderam ser observadas em microscópio óptico convencional, identificamos a expressão da AQP5 em todos os sítios de glândulas acinares rudimentares citados na literatura.

Gresz et al., (2015) descrevem que as regiões ductais em proximidade com os ácinos secretores de glândulas labiais menores em humanos adultos 
não há imunorexpressão para AQP5. No entanto, pudemos identificar que a expressão desta proteína ocorre em ductos intercalares em ácinos labiais rudimentares das glândulas salivares de fetos em desenvolvimento. Analogamente, Sugimoto et al., (2013) identificaram a expressão de AQP5 na membrana apical de ácinos mucosos e serosos de glândulas submandibulares de ratos, além da membrana basolateral de ácinos mucosos. Tais resultados também foram encontrados em nossos espécimes humanos, em que a expressão de aquaporina 5 foi observada em ambos os tipos acinares em desenvolvimento. Adicionalmente, Larsen et al., (2011) não identificaram a expressão de AQP5 na vasculatura. Em nossos achados também não pudemos concluir que a aquaporina 5 expressa-se em estruturas vasculares, sendo necessário desenvolver futuros estudos para confirmar tal informação.

A expressão de AQP5 nas células dos cordões terminais de glândulas salivares de camundongo em desenvolvimento não foi detectada até o estágio pseudoglandular em estudos prévios (Larsen et al., 2011). Em contrapartida, observamos intensa e evidente expressão desta proteína em todas as fases do desenvolvimento glandular salivar humano, sendo mais difusa e pouco definida nas regiões apicais e basolaterais nos estágios de botão inicial. Glândulas salivares embrionárias de ratos, por sua vez, obtiveram um padrão de expressão irregular para AQP5 durante o curso do seu desenvolvimento, assemelhando-se ao padrão de expressão observado em nossos achados. Aure et al., (2011) identificaram AQP5 primeiramente na fase canalicular, tornando-se mais organizada na membrana luminal das células acinares nas fases mais tardias, em que também foi detectada na membrana celular dos ductos intercalares, participando do processo de transferência da água na formação salivar. Além de sua expressão na membrana apical acinar, a AQP5 foi detectada por todo o ducto intralobular no estágio de botão terminal, o que indica que a AQP5 desempenhe uma função importante durante o desenvolvimento embrionário das glândulas salivares.

Matsuki et al., (2005) relatam uma expressão citoplasmática difusa que pode representar a presença de AQP5 nos grânulos secretores. Já por meio da 
técnica de microscopia imunoeletrônica, este estudo também confirmou a presença de grânulos secretores acinares em região demarcadamente apical.

Peters et al., (2014) observaram que a aquaporina 5 é expressa apicalmente e lateralmente nas células do epitélio pró-acinar em cultivo de células de glândula submandibular, tornando-se mais evidente na região apical de acordo com o curso do desenvolvimento glandular. Esse achado corroboram diretamente nossos resultados, cuja expressão de AQP5 também foi encontrada na membrana basolateral em glândulas salivares humanas em desenvolvimento, de forma menos intensa nos estágios finais de maturação, concentrando-se nas membranas apicais de forma mais acentuada com 0 decorrer do desenvolvimento. Ainda, Aure et al., (2011) identificaram a expressão do RNA da aquaporina 5 nas glândulas salivares de ratos em desenvolvimento por meio da técnica RT-PCR, permitindo identificar a expressão desta proteína em todos os estágios do desenvolvimento incluídos no estudo, sendo que o padrão de expressão apical se tornava mais evidente conforme a evolução do desenvolvimento (maturação glandular), ainda com expressão citoplasmática. A expressão citoplasmática de aquaporina 5 foi observada de forma menos intensa nos estágios terminais do desenvolvimento também em nossos estudos.

Alguns autores descrevem a localização da AQP5 restrita e claramente confinada à membrana plasmática apical das células acinares rudimentares durante o desenvolvimento. Outros autores por sua vez, definem a expressão da AQP5 também nas membranas basolaterais. Em ratos, apesar de ter-se detectado AQP5 nas membranas apicais e basolaterais, além da região citoplasmática, sua expressão nas células ductais permanece controversa (Ishikawa et al., 2006; Larsen et al., 2011; Teymoortash et al., 2012; Gresz et al., 2015).Em nosso trabalho, a imunoexpressão de AQP5 também pôde ser identificada nas membranas apicais do ducto intralobular nas fases de botão terminal, especificamente nas células próximas aos túbulos terminais e em toda a extensão do ducto intercalar. As demais regiões ductais foram negativas neste estudo. 
A expressão de aquaporinas no nosso estudo ao longo do desenvolvimento glandular humano, principalmente AQP3 e 5, interessantemente torna-se menos difusa no citoplasma de células ductais à medida que o espaço luminal se instala. A estrutura ductal é mais frequentemente encontrada nas fases mais tardias. Estudos recentes investigam os mecanismos envolvidos no processo de expansão luminal de ductos que permitam sua formação e a manutenção do espaço adequado para secreção. Relata-se que exista uma repulsão eletrolítica dentro dos ductos em formação ocasionada pela ativação de canais iônicos das células que estimulam a expansão luminal e contribuem para a morfogênse ductal, como já relatado em vasos sanguíneos (Strilic et al., 2010; Datta et al., 2011). Essa hipótese fundamenta os nossos achados, indicando que a importante expressão das aquaporinas durante o desenvolvimento glandular humano tenha realmente um papel crucial para a formação glandular, e não somente para estímulo secretório salivar, porém estudos futuros são necessários para esclarecer essa relação.

Akamatsu et al., (2003) identificaram, por meio da imunoistoquímica, a presença de AQP5 no sistema de vasculatura das glândulas submandibulares de ratos. Em nossos achados, porém, não foi possível observar expressão de aquaporina 5 em capilares ou vasos.

O envolvimento de AQP5 em processos tumorais já foi descrito em relação a seu mecanismo de invasão e progressão de vários tipos de câncer em humanos, sendo que, em pacientes com câncer de cólon, a superexpressão das aquaporinas 1,3 e 5 foi correlacionada de forma significativa com metástase ganglionar. Evidências apontam aquaporina 5 como um alvo promissor para o desenvolvimento de fármacos e como um biomarcador com potencial terapêutico e diagnóstico. (Kang et al., 2015; Direito et al., 2016).

A etapa laboratorial e análise dos resultados topográficos das aquaporinas gerou questionamentos, ainda não explorados na literatura, com especial destaque para as aquaporinas 1. Apesar de amplamente descrita na literatura em modelo animal e glândulas salivares adultas, não foi possível 
afirmar de forma categórica que AQP1 se expresse nas células mioepiteliais de glândulas salivares humanas em desenvolvimento. Assim, nosso trabalho abre portas para novas pesquisas que elucidem o papel dessas importantes proteínas na morfogênese das glândulas salivares humanas. A pavimentação dessa pesquisa e a possibilidade de novas investigações irão, certamente, contribuir para o entendimento de doenças como as que levam à xerostomia, e, talvez possam auxiliar no desenvolvimento de terapias medicamentosas que utilizem esses canais de água.

Por fim, cremos que a identificação de diferenças interessantes na expressão das aquaporinas em modelos animais e tecido humano abra novas questões para serem investigadas cientificamente. A elucidação dessas questões podem não só beneficiar a área de conhecimentos básicos da morfogênese das glândulas salivares, mas também, a área aplicada, com novos marcadores e possíveis alvos terapêuticos das enfermidades que envolvem as glândulas salivares. 
7. CONCLUSÃO 


\section{CONCLUSÃO}

Nosso trabalho evidenciou a imunoexpressão das aquaporinas 1, 3 e 5 nas glândulas salivares humanas durante 0 período de embriogênese. A análise topográfica dessas proteínas nos permitiu identificar diferenças no padrão de expressão em diferentes sítios da estrutura glandular durante os diferentes estágios do desenvolvimento.

Com este trabalho podemos concluir alguns pontos principais:

- As aquaporinas 1, 3 e 5 investigadas nesse trabalho foram amplamente expressas em todas as fases do desenvolvimento das glândulas salivares humanas;

- A AQP1 foi marcadamente mais expressa em regiões acinares rudimentares durante as fases iniciais do desenvolvimento, tornando-se menos evidente nas fases canaliculares e ausente nas estruturas acinares terminais. Nos estágios onde foi possível observar a região de ducto intercalar, AQP1 expressou-se de forma intensa. Capilares e vasos sanguíneos expressaram aquaporina $1 \mathrm{em}$ todas as fases do desenvolvimento fetal humano.

- As AQP3 e AQP5 resultaram em padrões de expressão semelhantes durante o desenvolvimento glandular, mostrando um perfil citoplasmático difuso nas fases mais iniciais do desenvolvimento. A expressão de ambas proteínas tornou-se mais evidente nas estruturas membranosas em estágios mais tardios, tanto em região apical como basolateral, adquirindo padrões de marcação citoplasmáticos menos evidentes com o decorrer do processo de maturação. Em todos os espécimes onde puderam ser observados, ductos intercalares exibiram acentuado padrão de expressão. 


\section{REFERÊNCIAS BIBLIOGRÁFICAS}

Abascal F, Irisarri I, Zardoya R. Diversity and evolution of membrane intrinsic proteins. Biochim Biophys Acta. 2014; 1840(5):1468-1481.

Agre P. The 2009 Lindau Nobel Laureate Meeting: Peter Agre, Chemistry 2003. J Vis Exp. 2009; (34): 1565.

Agre P. The Aquaporin Water Channels. Proc Am Thorac Soc. 2006; Mar; 3(1): 5-13.

Agre P. Aquaporin water channels (Nobel Lecture). Angew Chem Int Ed Engl. 2004; Aug 20;43(33):4278-90.

Agre P, King LS, Yasui M, Guggino WB, Ottersen OP, Fujiyoshi Y, Engel A, Nielsen S. Aquaporin water channels--from atomic structure to clinical medicine. J Physiol. 2002; Jul 1;542(Pt 1):3-16.

Agre P, Saboori AM, Asimos A, Smith BL. Purification and partial characterization of the $\mathrm{Mr} 30,000$ integral membrane protein associated with the erythrocyte Rh(D) antigen. J Biol Chem. 1987; Dec 25;262(36):17497-503.

Agre P, Sasaki S, Chrispeels MJ. Aquaporins: a family of water channel proteins. Am J Physiol. 1993; Sep;265(3 Pt 2):F461.

Akamatsu T, Parvin MN, Murdiastuti K, Kosugi-Tanaka C, Yao C, Miki O, Kanamori N, Hosoi K. Expression and localization of aquaporins, members of the water channel family, during development of the rat submandibular gland. Pflugers Arch. 2003; Sep; 446(6):641-51.

Amano O, Mizobe K, Bando Y, Sakiyama K. Anatomy and histology of rodent and human major salivary glands: -overview of the Japan salivary gland societysponsored workshop-. Acta Histochem Cytochem. 2012; Oct; 31;45(5):241-50.

Asking B, Gjörstrup P. Synthesis and secretion of amylase in the rat parotid gland following autonomic nerve stimulation in vivo. Acta Physiol Scand. 1987; Jul;130(3):439-45. 
Aure MH, Larsen HS, Ruus AK, Galtung HK . Aquaporin 5 distribution pattern during development of the mouse sublingual salivary gland. J Mol Histol. 2011; Oct ; 42(5):401-8.

Avery J. Oral development and histology. Development, structure and function of salivary glands. $3^{\circ} \mathrm{ed}$. New York:Thieme; 2002

Baker OJ, Schulz DJ, Camden JM, Liao Z, Peterson TS, Seye CI, Petris MJ, Weisman GA. Rat parotid gland cell differentiation in three-dimensional culture. Tissue Eng Part C Methods. 2010; Oct; 16(5):1135-44

Berkovitz BKB, Holland GR, Moxham B.J. A Colour Atlas and Textbook of Oral Anatomy Histology and Embryology, ed. 2. Wolfe Publishing Ltd. 1992.

Beroukas D, Hiscock J, Gannon BJ, Jonsson R, Gordon TP, Waterman SA. Selective down-regulation of aquaporin-1 in salivary glands in primary Sjögren's syndrome. Lab Invest. 2002; Nov; 82(11):1547-52.

Beroukas D, Hiscock J, Jonsson R, Waterman SA, Gordon TP. Subcellular distribution of aquaporin 5 in salivary glands in primary Sjögren's syndrome. Lancet. 2001; Dec; 1;358(9296):1875-6.

Borgnia M, Nielsen S, Engel A, Agre P. Cellular and molecular biology of the aquaporin water channels. Annu Rev Biochem. 1999;68:425-58.

Carlson GW. The salivary glands. Embryology, anatomy, and surgical applications. Surg Clin North Am. 2000; Feb; 80(1):261-73.

Catalán MA, Nakamoto T, Melvin JE. The salivary gland fluid secretion mechanism. J Med Invest. 2009;56 Suppl:192-6.

Chen J, Wang T, Zhou YC, Gao F, Zhang ZH, Xu H, Wang SL, Shen LZ. Aquaporin 3 promotes epithelial-mesenchymal transition in gastric cancer. $J$ Exp Clin Cancer Res. 2014; May; 3;33:38.

Chitturi RT, Veeravarmal V, Nirmal RM, Reddy BV. Myoepithelial Cells (MEC) of the Salivary Glands in Health and Tumours. J Clin Diagn Res. 2015; Mar; 9(3):ZE14-8. 
Cutler LS. The role of extracellular matrix in the morphogenesis and differentiation of salivary glands. Adv Dent Res. 1990; 4:27-33.

Dale AC. Salivary gland. In: Ten Cate AR, editor. Oral Histology. 4th edn. St. Louis: Mosby; 1994; p. 312-333

Dale BA, Salonen J, Jones AH. New approaches and concepts in the study of differentiation of oral epithelia. Crit Rev Oral Biol Med. 1990;1(3):167-90.

Datta A, Bryant D, Mostov, KE. Molecular Regulation of Lumen Morphogenesis. Curr Biol. 2011; 21: R126-R136.

Dawes C. Rhythms in salivary flow rate and composition. Int J Chronobiol. 1974;2(3):253-79.

Delporte C. Role of aquaporins in saliva secretion. OA Biochemistry. 2013; Sep; $01 ; 1(2): 14$.

Delporte C, Steinfeld S. Distribution and roles of aquaporins in salivary glands. Biochim Biophys Acta. 2006; Aug; 1758(8):1061-70.

Denny PC, Ball WD, Redman RS. Salivary glands: a paradigm for diversity of gland development. Crit Rev Oral Biol Med. 1997; 8(1):51-75.

Direito I, Madeira A, Brito MA, Soveral G. Aquaporin-5: from structure to function and dysfunction in cancer. Cell Mol Life Sci. 2016. Apr;73(8):1623-40.

Dodds MW, Johnson DA, Yeh CK. Health benefits of saliva: a review. J Dent. 2005; Mar;33(3):223-33.

Edgar WM. Saliva: its secretion, composition and functions. Br Dent J. 1992, Apr 25;172(8):305-12.

Edgar WM. Saliva and dental health. Clinical implications of saliva: report of a consensus meeting. Br Dent J. 1990; Aug 11-25;169(3-4):96-8.

Ellis GL, Auclair PL. AFIP Atlas of Tumor Pathology: The normal salivary glands. $4^{\circ}$ ed. Maryland: ARP Press; 2008; p. 1-20. 
Ferraris ME, Munõz AC. Histologia e Embriologia Bucodental: Bases Estruturais da Patologia, diagnóstico, tratamento e prevenção odontológica. $2^{\circ}$ edição Editorial Médica Panamericana Guanabara Koogan. 2006; p.139-169. Ferreira JN, Hoffman MP. Interactions between developing nerves and salivary glands. Organogenesis. 2013; Jul-Sep; 9(3):199-205.

Filho JA, Imamura R, Sennes LU. Benign Neoplasms of the Salivary Glands. International Archives of otorhinolaryngology. 2002; (Vol. 6 Num. 3 - July/Sept)

Fitzgerald MJT. Embriologia Humana: Ciências Médicas. 1aㅡ ed. São Paulo: Harper e Row do Brasil; 1980.

Foskett JK. [Ca2+]i modulation of $\mathrm{Cl}$ - content controls cell volume in single salivary acinar cells during fluid secretion. Am J Physiol. 1990; Dec;259(6 Pt 1):C998-1004.

Foskett JK, Melvin JE. Activation of salivary secretion: coupling of cell volume and [Ca2+]i in single cells. Science. 1989, Jun 30;244(4912):1582-5.

Garrett JR. The proper role of nerves in salivary secretion: a review. J Dent Res. 1987; 66:387-397.

Ghasemlou N, Krol KM, Macdonald DR, Kawaja MD. Comparison of target innervation by sympathetic axons in adult wild type and heterozygous mice for nerve growth factor or its receptor trkA. J Pineal Res. 2004; Nov;37(4):230-40.

Gregoire $F$, Lucidi V, Zerrad-Saadi A, Virreira $M$, Bolaky $N$, Delforge $V$, Lemmers A, Donckier V, Devière J, Demetter P, Perret J, Delporte C. Analysis of aquaporin expression in liver with a focus on hepatocytes. Histochem Cell Biol. 2015; Oct; 144(4):347-63.

Gresik EW. The granular convoluted tubule (GCT) cell of rodent submandibular glands. Microsc Res Tech. 1994; Jan 1;27(1):1-24.

Gresz V, Burghardt B, Ferguson CJ, Hurley PT, Takács M, Nielsen S, Varga G, Zelles T, Case RM, Steward MC. Expression of aquaporin 1 (AQP1) water channels in human labial salivary glands. Arch Oral Biol. 1999; May; 44 Suppl 1:S53-7. 
Gresz V, Horvath A, Gera I, Nielsen S, Zelles T. Immunolocalization of AQP5 in resting and stimulated normal labial glands and in Sjögren's syndrome. Oral Diseases. 2015; Jan;21;e114-e120.

Gresz V, Kwon TH, Hurley PT, Varga G, Zelles T, Nielsen S, Case RM, Steward MC. Identification and localization of aquaporin water channels in human salivary glands. Am J Physiol Gastrointest Liver Physiol. 2001; Jul; 281(1):G247-54.

Hara-Chikuma M, Verkman AS. Roles of aquaporin-3 in the epidermis. J Invest Dermatol. 2008; Sep;128(9):2145-51.

Hara-Chikuma M, Verkman AS. Physiological roles of glycerol-transporting aquaporins: the aquaglyceroporins. Cell Mol Life Sci. 2006 Jun;63(12):1386-92.

Hardy G, Kramer B. The myoepithelium of human major salivary glands revisited. SADJ. 1998; Jul; 53(7):371-5.

He X, Tse CM, Donowitz M, Alper SL, Gabriel SE, Baum BJ. Polarized distribution of key membrane transport proteins in the rat submandibular gland. Pflugers Arch. 1997; Jan;433(3):260-8.

Hector MP, Linden RWA. Reflexes of salivary secretion. In: Garrett JR, Ekström J, Andersson LC, (eds). Neural mechanisms of salivary gland secretion. Basel: Karger, 1999. p.196-217

Hogan BL. Morphogenesis. Cell. 1999 Jan 22;96(2):225-33.

Holmberg KV, Hoffman MP. Anatomy, biogenesis and regeneration of salivary glands. Monogr Oral Sci. 2014; May; 23;24:1-13.

Hosoi K. Physiological role of aquaporin 5 in salivary glands. 2016. Pflugers Arch. 2016; Apr;468(4):519-39.

Hsu JC, Yamada KM. Salivary gland branching morphogenesis-recent progress and future opportunities. Int J Oral Sci. 2010; Sep; 2(3):117-26. 
Huang YH, Zhou XY, Wang HM, Xu H, Chen J, Lv NH. Aquaporin 5 promotes the proliferation and migration of human gastric carcinoma cells. Tumour Biol. 2013; Jun; 34(3):1743-51.

Humphrey SP, Williamson RT. A review of saliva: normal composition, flow, and function. J Prosthet Dent. 2001; Feb; 85(2):162-9.

lanez RF, Buim ME, Coutinho-Camillo CM, Schultz R, Soares FA, Lourenço SV. Human salivary gland morphogenesis: myoepithelial cell maturation assessed by immunohistochemical markers. Histopathology. 2010; Sep; 57(3):410-7.

Ishibashi $\mathrm{K}$, Kondo $\mathrm{S}$, Hara S, Morishita $\mathrm{Y}$. The evolutionary aspects of aquaporin family. Am J Physiol Regul Integr Comp Physiol. 2011; Mar; 300(3):R566-76.

Ishibashi K, Tanaka Y, Morishita Y. The role of mammalian superaquaporins inside the cell. Biochim Biophys Acta. 2014 May;1840(5):1507-12.

Ishikawa Y, Cho G, Yuan Z, Inoue N, Nakae Y. Aquaporin-5 water channel in lipid rafts of rat parotid glands. Biochimica et Biophysica Acta. 2006 Aug; 1758(8):1053-60.

Ishikawa Y, Eguchi T, Skowronski MT, Ishida H. Acetylcholine acts on M3 muscarinic receptors and induces the translocation of aquaporin5 water channel via cytosolic $\mathrm{Ca} 2+$ elevation in rat parotid glands. Biochem Biophys Res Commun. 1998; Apr 28;245(3):835-40.

Ishikawa $Y$, Ishida H. Aquaporin water channel in salivary glands. Jpn $J$ Pharmacol. 2000; Jun; 83(2):95-101.

Ishikawa $\mathrm{Y}$, Skowronski MT, Ishida H. Persistent increase in the amount of aquaporin-5 in the apical plasma membrane of rat parotid acinar cells induced by a muscarinic agonist SNI-2011. FEBS Lett. 2000; Jul 21;477(3):253-7. 
Jaskoll T, Melnick M. Submandibular gland morphogenesis: stage-specific expression of TGF-alpha/EGF, IGF, TGF-beta, TNF, and IL-6 signal transduction in normal embryonic mice and the phenotypic effects of TGFbeta2, TGF-beta3, and EGF-r null mutations. Anat Rec. 1999; Nov $1 ; 256(3): 252-68$.

Jung JS, Preston GM, Smith BL, Guggino WB, Agre P. Molecular structure of the water channel through aquaporin CHIP. The hourglass model. J Biol Chem. 1994; May 20;269(20):14648-54.

Junqueira LCU, Zago D. Embriologia médica e comparada. 3.ed. Rio de Janeiro: Guanabara Koogan, 1982. P. 4-45.

Kang BW, Kim JG, Lee SJ, Chae YS, Jeong JY, Yoon GS, Park SY, Kim HJ, Park JS, Choi GS, Jeong JY. Expression of aquaporin-1, aquaporin-3, and aquaporin-5 correlates with nodal metastasis in colon cancer. Oncology. 2015; 88(6):369-76.

Kashimata M, Gresik EW. Contemporary approaches to the study of salivary gland morphogenesis. Eur J Morphol. 1996; Aug;34(3):143-7.

Katchburian E, Arana V. Histologia e Embriologia Oral - Texto, Atlas e Correlações Clinicas. $3^{\circ} \mathrm{ed}$. Rio de Janeiro: Guanabara-Koogan; 2014;

King LS, Agre P. Pathophysiology of the aquaporin water channels. Annu Rev Physiol. 1996; 58:619-48.

King LS, Kozono D, Agre P. From structure to disease: the evolving tale of aquaporin biology. Nat Rev Mol Cell Biol. 2004; Sep; 5(9):687-98.

Klein RM. Development, structure and function of salivary glands. In: Avery JK, editor. Oral Development and Histology. 2nd edn. New York: Thieme; 1994. p. 352-379.

Knox SM, Hoffman MP. Salivary gland development. Ames, IA: Blackwell Publication. 2008. 
Knox SM, Lombaert IM, Reed X, Vitale-Cross L, Gutkind JS, Hoffman MP. Parasympathetic innervation maintains epithelial progenitor cells during salivary organogenesis. Science. 2010; Sep 24;329(5999):1645-7.

Kozono D, Yasui M, King LS, Agre P. Aquaporin water channels: atomic structure molecular dynamics meet clinical medicine. J Clin Invest. 2002; Jun; 109(11):1395-9.

Krane CM, Melvin JE, Nguyen HV, Richardson L, Towne JE, Doetschman T, Menon AG. Salivary acinar cells from aquaporin 5-deficient mice have decreased membrane water permeability and altered cell volume regulation. $J$ Biol Chem. 2001; Jun; 276(26):23413-20.

Kruse E, Uehlein N, and Kaldenhoff R. The aquaporins. Genome Biol. 2006; $7(2): 206$.

Lammert E, Cleaver O, Melton D. Role of endothelial cells in early pancreas and liver development. Mech Dev. 2003; Jan;120(1):59-64.

Larsen HS. Aure MH, Peters ASB, Larsen M, Messelt EB, Galtung HK. Localization of AQP5 during development of the mouse submandibular salivary gland. J Mol Hist. 2011; 42:71-81.

Larsen HS, Ruus AK, Galtung HK. Aquaporin expression patterns in the developing mouse salivary gland. Eur J Oral Sci. 2009; Dec;117(6):655-62

Larsen M, Yamada KM, Musselmann K. Systems analysis of salivary gland development and disease. Wiley Interdiscip Rev Syst Biol Med. 2010; NovDec;2(6):670-82.

Lee MD, Bhakta KY, Raina S, Yonescu R, Griffin CA, Copeland NG, Gilbert DJ, Jenkins NA, Preston GM, Agre P. The human Aquaporin-5 gene. Molecular characterization and chromosomal localization. J Biol Chem. 1996; Apr;12;271(15):8599-604.

Lee MG, Ohana E, Park HW, Yang D, Muallem S. Molecular mechanism of pancreatic and salivary gland fluid and HCO3 secretion. Physiol Rev. 2012; Jan;92(1):39-74. 
Liu F, Wang S. Molecular cues for development and regeneration of salivary glands. Histol Histopathol. 2014; Mar; 29(3):305-12.

Lourenço SV, Coutinho-Camillo CM, Buim ME, Uyekita SH, Soares FA. Human salivary gland branching morphogenesis: morphological localization of claudins and its parallel relation with developmental stages revealed by expression of cytoskeleton and secretion markers. Histochem Cell Biol. 2007; Oct; 128(4):361-9.

Lourenço SV, Uyekita SH, Lima DM, Soares FA. Developing human minor salivary glands: morphological parallel relation between the expression of TGFbeta isoforms and cytoskeletal markers of glandular maturation. Virchows Arch. 2008; Apr; 452(4):427-34.

Lu P, Sternlicht MD, Werb Z. Comparative Mechanisms of Branching Morphogenesis in Diverse Systems. J Mammary Gland Biol Neoplasia. 2006; Oct; 11(3-4): 213-228.

Lu P, Werb Z. Patterning mechanisms of branched organs. Science. 2008; Dec 5;322(5907):1506-9.

Ma T, Hara M, Sougrat R, Verbavatz JM, Verkman AS. Impaired stratum corneum hydration in mice lacking epidermal water channel aquaporin-3. J Biol Chem. 2002; May 10;277(19):17147-53.

Ma T, Song Y, Gillespie A, Carlson EJ, Epstein CJ, Verkman AS. Defective secretion of saliva in transgenic mice lacking aquaporin-5 water channels. J Biol Chem. 1999; Jul;16;274(29):20071-4.

Ma T, Song Y, Yang B, Gillespie A, Carlson EJ, Epstein CJ, Verkman AS. Nephrogenic diabetes insipidus in mice lacking aquaporin-3 water channels. Proc Natl Acad Sci U S A. 2000; Apr 11;97(8):4386-91.

Ma T, Verkman AS. Aquaporin water channels in gastrointestinal physiology. $J$ Physiol. 1999; Jun; 517(Pt 2): 317-326. 
Macauley SP, Tarnuzzer RW, Schultz GS, Chegini N, Oxford GE, HumphreysBeher MG. Extracellular-matrix gene expression during mouse submandibular gland development. Arch Oral Biol. 1997; Jun;42(6):443-54.

Madeira MC. Anatomia da face: bases anátomo-funcionais para a prática odontológica. $6^{\circ}$ ed. São Paulo: Sarvier; 2008; p. 124-51

Matsuki M, Hashimoto S, Shimono M, Murakami M, Fujita-Yoshigaki J, Furuyama S, Sugiya H. Involvement of aquaporin-5 water channel in osmoregulation in parotid secretory granules. J Membr Biol. 2005; Feb;203(3):119-26.

Matsuzaki T, Suzuki T, Takata K. Hypertonicity-induced expression of aquaporin 3 in MDCK cells. Am J Physiol Cell Physiol. 2001; Jul;281(1):C55-63.

Matsuzaki T, Tajika Y, Ablimit A, Aoki T, Hagiwara H, Takata K. Aquaporins in the digestive system. Med Electron Microsc. 2004; Jun;37(2):71-80.

Mcbride MI, Baillie J, Poland BJ. Growth parameters in normal fetuses. Teratology. 1984; 29:185-191.

Melnick M, Jaskoll T. Mouse submandibular gland morphogenesis: a paradigm for embryonic signal processing. Crit Rev Oral Biol Med. 2000;11(2):199-215.

Melvin JE, Yule D, Shuttleworth T, Begenisich T. Regulation of fluid and electrolyte secretion in salivary gland acinar cells. Annu Rev Physiol. 2005;67:445-69.

Mobasheri A, Barrett-Jolley R. Aquaporin water channels in the mammary gland: from physiology to pathophysiology and neoplasia. J Mammary Gland Biol Neoplasia. 2014; Mar;19(1):91-102.

Morishita Y, Sakube Y, Sasaki S, Ishibashi K. Molecular mechanisms and drug development in aquaporin water channel diseases: aquaporin superfamily (superaquaporins): expansion of aquaporins restricted to multicellular organisms. J Pharmacol Sci. 2004; Nov;96(3):276-9. 
Mulders SM, Preston GM, Deen PM, Guggino WB, van Os CH, Agre P. Water channel properties of major intrinsic protein of lens. J Biol Chem. 1995; Apr 14;270(15):9010-16.

Munger BL. Histochemical studies on seromucous- and mucous-secreting cells of human salivary glands. Am J Anat. 1964; Nov;115:411-29.

Musa-Aziz R, Chen LM, Pelletier MF, Boron WF. Relative CO2/NH3 selectivities of AQP1, AQP4, AQP5, AmtB, and RhAG. Proc Natl Acad Sci U S A. 2009; Mar 31;106(13):5406-11.

Naesse EP, Schreurs O, Messelt E, Hayashi K, Schenck K.. Distribution of nerve growth factor, pro-nerve growth factor, and their receptors in human salivary glands. Eur J Oral Sci. 2013; Feb;121(1):13-20.

Nedvetsky PI, Emmerson E, Finley JK, Ettinger A, Cruz-Pacheco N, Prochazka J, Haddox CL, Northrup E, Hodges C, Mostov KE, Hoffman MP, Knox SM.. Parasympathetic innervation regulates tubulogenesis in the developing salivary gland. Dev Cell. 2014; Aug 25;30(4):449-62.

Nelson DA, Manhardt C, Kamath V, Sui Y, Alberto Santamaria-Pang A, Can A, Bello M, Corwin A, Dinn SR, Lazare M, Gervais EM, Sequeira SJ, Peters SB, Ginty F, Gerdes MJ, Larsen M. Quantitative single cell analysis of cell population dynamics during submandibular salivary gland development and differentiation. Biol Open. 2013; Apr;18;2(5):439-47.

Ogawa Y. Immunocytochemistry of myoepithelial cells in the salivary glands. Prog Histochem Cytochem. 2003; 38(4):343-426.

Otani H, Udagawa J, Hatta T, Kagohashi Y, Hashimoto R, Matsumoto A, Satow $\mathrm{F}$, Nimura M. Individual variation in organ histogenesis as a causative factor in the developmental origins of health and disease: unnoticed congenital anomalies? Congenit Anom (Kyoto). 2010; Dec;50(4):205-11

Papadopoulos MC, Saadoun S, Verkman AS. Aquaporins and cell migration. Pflugers Arch. 2008; Jul; 456(4):693-700. 
Patel VN, Hoffman MP. Salivary gland development: a template for regeneration. Semin Cell Dev Biol. 2014; Jan-Feb; 25-26:52-60.

Patel VN, Rebustini IT, Hoffman MP. Salivary gland branching morphogenesis. Differentiation. 2006; Sep; 74(7):349-64.

Peters SB, Naim N, Nelson DA, Mosier AP, Cady NC, Larsen M. Biocompatible tissue scaffold compliance promotes salivary gland morphogenesis and differentiation. Tissue Eng Part A. 2014; Jun;20(11-12):1632-42.

Preston GM, Agre P.Isolation of the CDNA for erythrocyte integral membrane protein of 28 kilodaltons: member of an ancient channel family. Proc Natl Acad Sci U S A. 1991; Dec 15;88(24):11110-4.

Preston GM, Carroll TP, Guggino WB, Agre P. Appearance of water channels in Xenopus oocytes expressing red cell CHIP28 protein. Science. 1992; 256:38587.

Proctor GB. The physiology of salivary secretion. Periodontol 2000. 2016; Feb;70(1):11-25.

Proctor GB, Carpenter GH. Regulation of salivary gland function by autonomic nerves. Auton Neurosci. 2007; Apr 30;133(1):3-18.

Redman RS. Myoepithelium of salivary glands. Microsc Res Tech. 1994; Jan 1;27(1):25-45.

Rojek A, Praetorius J, Frøkiaer J, Nielsen S, Fenton RA. A current view of the mammalian aquaglyceroporins. Annu Rev Physiol. 2008;70:301-27.

Rossoni RB, Machado CR, Machado AB. Autonomic innervation of salivary glands in the armadillo, anteater, and sloth (Edentata). J Morphol. 1981; May;168(2):151-7

Roth G, Calmes R. Salivary glands and saliva. Oral biology: CV Mosby, St Louis; 1981; p.196-236

Rudney JD. Does variability in salivary protein concentrations influence oral microbial ecology and oral health? Crit Rev Oral Biol Med. 1995;6(4):343-67. 
Saadoun S, Papadopoulos MC, Davies DC, Bell BA, Krishna S. Increased aquaporin 1 water channel expression in human brain tumours. $\mathrm{Br} J$ Cancer. 2002; Sep 9;87(6):621-3.

Saadoun S, Papadopoulos MC, Hara-Chikuma M, Verkman AS. Impairment of angiogenesis and cell migration by targeted aquaporin-1 gene disruption. Nature. 2005; Apr; 434(7034):786-92.

Saito K, Mori S, Date F, Hong G. Epigallocatechin gallate stimulates the neuroreactive salivary secretomotor system in autoimmune sialadenitis of MRLFaslpr mice via activation of cAMP-dependent protein kinase $A$ and inactivation of nuclear factor KB. Autoimmunity. 2015; Apr; 7:1-10.

Sato A, Miyoshi S. Cells in the duct system of the rat submandibular gland. Eur J Morphol. 1998; Aug;36 Suppl:61-6.

Shan T, Cui X, Li W, Lin W, Li Y. AQP5: A novel biomarker that predicts poor clinical outcome in colorectal cancer. Oncol Rep. 2014; Oct; 32(4):1564-70.

Shannon IL, Suddick RP, Chauncey HH. Effect of atropine-induced flow rate depression on the composition of unstimulated human parotid fluid. Arch Oral Biol. 1969; Jul;14(7):761-70.

Sidhaye VK, Chau E, Srivastava V, Sirimalle S, Balabhadrapatruni C, Aggarwal NR, D'Alessio FR, Robinson DN, King LS. A novel role for aquaporin-5 in enhancing microtubule organization and stability. PLOS One. 2012; 7(6):e38717.

Sivakumar, M, Sud. M; Vathsal, V. Histogenesis And Morphometric Study Of Human Foetal Submandibular Salivary Gland. J Anat. Soc. India. 2003; 52(1) 36.

Smith BL, Agre P. Erythrocyte Mr 28,000 transmembrane protein exists as a multisubunit oligomer similar to channel proteins. J Biol Chem. 1991; Apr 5;266(10):6407-15. 
Speirs RL. Secretion of saliva by human lip mucous glands and parotid glands in response to gustatory stimuli and chewing. Arch Oral Biol. 1984; 29(11):9458.

Sreebny LM. Saliva in health and disease: an appraisal and update. Int Dent J. 2000; Jun;50(3):140-61.

Steward MC, Seo Y, Murakami M, Seo JT, Larcombe-McDouall JB, Case RM. Regulation of cell volume and diffusion of intracellular water in salivary acinar cells. Eur J Morphol. 1998; Aug;36 Suppl:103-6.

Strilic, B., Eglinger, J., Krieg, M., Zeeb, M., Axnick, J., Babal, P., Muller, D.J., and Lammert, E. Elecrostatic cell surface repulsion initiates lumen formation in developing blood vessels. Curr. Biol. 2010; 20: 2003-9.

Sugimoto N, Matsuzaki K, Ishibashi H, Tanaka M, Sawaki T, Fujita $\mathrm{Y}$, Kawanami T, Masaki Y, Okazaki T, Sekine J, Koizumi S, Yachie A, Umehara H, Shido $\mathrm{O}$. Upregulation of aquaporin expression in the salivary glands of heatacclimated rats. Sci Rep. 2013; 3:1763.

Tamarin A. Myoepithelium of the rat submaxillary gland. J Ultrastruct Res. 1966; Oct;16(3):320-38.

Ten Cate A. Histologia Oral: desenvolvimento, estrutura e função. $8^{\circ}$ ed. Rio de Janeiro: Guanabara Koogan; 2013.

Terashima I, Ono K. Effects of $\mathrm{HgCl}(2)$ on $\mathrm{CO}(2)$ dependence of leaf photosynthesis: evidence indicating involvement of aquaporins in $\mathrm{CO}(2)$ diffusion across the plasma membrane. Plant Cell Physiol. 2002 Jan;43(1):70-8.

Teshima TH, lanez RF, Coutinho-Camillo CM, Buim ME, Soares FA, Lourenço SV. Development of human minor salivary glands: expression of mucins according to stage of morphogenesis. J Anat. 2011; Sep; 219(3):410-7.

Teshima TH, lanez RC, Coutinho-Camillo CM, Tucker AS, Lourenço SV. Apoptosis-associated protein expression in human salivary gland morphogenesis. Arch Oral Biol. 2016; May 17;69:71-81. 
Teymoortash A, Wiegand S, Borkeloh M, Bette M, Ramaswamy A, SteinbachHundt S, Neff A, Werner JA, Mandic R. Variations in the expression and distribution pattern of AQP5 in acinar cells of patients with sialadenosis. In Vivo. 2012; Nov-Dec; 26 (6):951-5.

Tiwari M. Science behind human saliva. J Nat Sci Biol Med. 2011; Jan; 2(1):53865.

Tucker AS. Salivary gland development. Semin Cell Dev Biol. 2007; Apr; 18 (2):237-44.

Turner RJ, Paulais M, Manganel M, Lee SI, Moran A, Melvin JE. Ion and water transport mechanisms in salivary glands. Crit Rev Oral Biol Med. 1993;4(34):385-91.

Turner RJ, Sugiya H. Understanding salivary fluid and protein secretion. Oral Dis. 2002; Jan;8(1):3-11.

Varner VD, Nelson CM. Cellular and physical mechanisms of branching morphogenesis. Development. 2014; Jul;141(14):2750-9.

Verkman AS. Aquaporins in endothelia. Kidney Int. 2006; Apr;69(7):1120-3.

Verkman AS. More than just water channels: unexpected cellular roles of aquaporins. J Cell Sci. 2005 Aug 1;118(Pt 15):3225-32.

Verkman AS. Aquaporin water channels and endothelial cell function. J Anat. 2002; Jun; 200(6):617-27.

Verkman AS, Hara-Chikuma M, Papadopoulos MC. Aquaporins-new players in cancer biology. J Mol Med. 2008; 86: 523-529, .

Walz T, Hirai T, Murata K, Heymann JB, Mitsuoka K, Fujiyoshi Y, Smith BL, Agre P, Engel A. The three-dimensional structure of aquaporin-1. Nature. 1997; Jun 5;387(6633):624-7.

Winning TA, Townsend GC. Oral mucosal embryology and histology. Clin Dermatol. 2000; Sep-Oct; 18(5):499-511. 
Wolpert, L., Tickle, C., \& Arias, A. M. Principles of development. $5^{\circ}$ ed. Oxford University Press, USA. 2015.

Yool AJ. Functional domains of aquaporin-1: keys to physiology, and targets for drug discovery. Curr Pharm Des. 2007;13(31):3212-21.

Zeuthen T, Klaerke DA. Transport of water and glycerol in aquaporin 3 is gated by H(+).J Biol Chem. 1999; Jul 30;274(31):21631-6.

Zhou Y, Wang Y, Wen J, Zhao H, Dong X, Zhang Z, Wang S, Shen L. Aquaporin 3 promotes the stem-like properties of gastric cancer cells via Wnt/GSK-3 $\beta / \beta$-catenin pathway. Oncotarget. 2016; Feb 24. doi: 10.18632/oncotarget.7664. [Epub ahead of print]

Zhu C, Jiang Z, Bazer FW, Johnson GA, Burghardt RC, Wu G. Aquaporins in the female reproductive system of mammals. Front Biosci (Landmark Ed). 2015; Jan 1;20:838-71. 


\section{ANEXOS}

\subsection{Aprovação do Comitê de Ética}

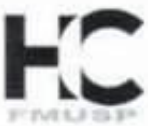

Hospital das Clínicas da FMUSP

Comissăo de Ética para Análise de Projetos de Pesquisa - CAPPesa

\section{PROJETO DE PESQUISA}

Titulo: ESTUDO MORFOLOGICO E AVALAAČ̆O DA EXPRESSÃO PHOTEICA DAS AQUAPORINAS DE GLANDULAS SALNARES DA MUCOSA ORAL EM DESENVOLVIMENTO E GLANDULAS SALIVARES COMPROMETIDAS PELASINDROME DE SIOGREN Pesquisador Responsavet: Silvia Vanessa Lourenço Versalo: 2 Pesquisador Executante: Fernanda de Paula CAAE: 19775213.0 .0000 .0068 Co-autores: Dr. Ricardo Hsieh

Finalidade Acadtmica: Mestrado

Orientadon: Profa. Dra. Silvia Vanessa Lourenço

Instituiçlo: HCFMUSP

Departamento: OERMATOLOGU

\section{PARECER CONSUBSTANCIADO DO CEP}

Registro on-line: 11168

Número do Parecen: $\mathbf{4 5 6 . 0 9 0}$

Data da Relatoria: $13 / 11 / 13$ - od referendum

Apresentaça do Projeto: Projeto realizara analise de material de biopsia contendo tecido de mucosa oral, cujo diagnóstico clinico e histopatológico ef de Sindrome de Sjogren 130 pacientes) - material contendo tecido de mucosa oral fetal entre 14-25 semanas de desenvolvimento (20 amostras). O material pertence ao arquivo do Departamento de Dermatologia da Faculdade de Medicina da Universidade de S\$o Paulo.

Objetivo da Pesquisa: investigar as alteraçoes morfologicas e histopatologicas das glandulas salivares das mucosas relacionadas aos sintomas de xerostomia dos pacientes com diagnostico de Sindrome de sjogren e de gilindulas salivares em diveras fases de desenvolvimento, atraves da andilse da expresslo proteica das aquaporinas.

Avaliaşo dos Riscos e Beneficios: N3o hà risco ao sujeito de pesquina, pois a andlise será realizada em tecido já previamente coletado e estocado no Departamento de Dermatologia.

Comentarios e Consideraç̋es sobre a Pesquisa: Pesquisa pertinente, pois ha poucos estudos que tentam esclarecer a fisiopatologia da xerostomia na Sindrome de Sjogren.

Consideraçðes sobre os Termos de apresentaçăo obrigatória: foi enviado o documente autorizando a perquirador executante a utilizar as amostras estocadas.

Rua Dr, Ovidio Pires de Campor, 225 - Predio da Administracáo - 59 andar CEP 05403-010 - 5 to Paulo - 5 ?

55 112661.7585 - $55112661-6442$ ramais: $16,17,18$ | marcia carvalhoehc fm usp.be 
Hospital das Clínicas da FMUSP

Comissăo de Ética para Análise de Projetos de Pesquisa - CAPPesq

Recomendaçöes: Recomenda-se aprovaç̧o.

Conclusōes ou Pendencias e Lista de Inadequaçōes: Aprovado.

Situaçlo do Parecer: Aprovado.

Necessita A preciaç̃o da CONEP: N\$̊.

Consideraçôes Finais a criterio do CEP: Em conformidade com a Resoluç\$o CNS $n$ * 466/12 cabe ao pesquisador a) desenvolver o projeto conforme delineado; b) elaborar e apresentar relatórios parciais e finat; c)apresentar dados solicitados pelo CEP, a qualquer momento; d) manter em arquivo sob sua guarda, por $\mathbf{S}$ anos da pesquisa, contendo fichas individuais e todos os demais documentos recomendados pelo CEP; e) encaminhar os resultados para publicaçăo, com os devidos créditos aos pesquisadores associados e ao pessoal técnico participante do projeto; f justificar perante ao CEP interrups\$o do projeto ou a nlo publicaç̧o dos resultados.

SSo Paulo, 13 de Novembro de 2013 aypdranur

Prot Dr. Alfedo Jose Mansur

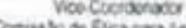

Ponsule of Elca jas hulise a

Rua Dr. Ovidio Pires de Campos, 225 - Predio da Administraclo - 59 andar CEP 05403-010-5So Paulo - 5P.

S5 11 2661-7585 - $55112661-6442$ ramais: $16,17,18$ | matciacarvalho ehc fmusp. br 